\title{
The funerary and architectural history of an ancient Maya residential group: Group 5N6, Naachtun, Guatemala
}

La secuencia funeraria y arquitectónica de un grupo residencial maya: el Grupo 5N6, Naachtun, Guatemala

La séquence funéraire et architecturale d'un groupe résidentiel maya : le

Groupe 5N6, Naachtun, Guatemala

Hemmamuthé Goudiaby and Philippe Nondédéo

\section{OpenEdition}

\section{Journals}

Electronic version

URL: https://journals.openedition.org/jsa/17846

DOI: $10.4000 /$ jsa. 17846

ISSN: 1957-7842

Publisher

Société des américanistes

Printed version

Date of publication: 30 June 2020

Number of pages: 19-64

ISBN: 978-2-902715-13-8

ISSN: 0037-9174

\section{Electronic reference}

Hemmamuthé Goudiaby and Philippe Nondédéo, "The funerary and architectural history of an ancient Maya residential group: Group 5N6, Naachtun, Guatemala", Journal de la Société des américanistes [Online], 106-1 | 2020, Online since 30 June 2020, connection on 26 September 2022. URL: http:// journals.openedition.org/jsa/17846 ; DOI: https://doi.org/10.4000/jsa.17846 


\title{
The funerary and architectural history of an ancient Maya residential group: Group 5N6, Naachtun, Guatemala
}

\author{
Hemmamuthé GoudiaBY and Philippe NondÉDÉO *
}

\begin{abstract}
The majority of ancient Maya funerary contexts, at least those reported by archaeology, are residential in nature. This cultural specificity, while it renders the excavation process more complex, establishes a link between the grave and the surrounding buildings. In turn, this association allows for a very high chronological resolution in reconstructing the history of these residences and the lives of their inhabitants. At Naachtun (Petén, Guatemala), intensive excavations in the residential Group 5N6 over three field seasons yielded important data on the formation and evolution of an ancient Maya residential compound linked to the local elite. The results question the way the inhabitants envisioned and planned their living space and allow us to illustrate the existence of various funerary pathways among the ancient Maya. [Keywords: ancient Maya, funerary practices, residential space, sequence, archaeothanatology.]
\end{abstract}

La secuencia funeraria y arquitectónica de un grupo residencial maya: el Grupo 5N6, Naachtun, Guatemala. En su mayoría, los contextos funerarios descubiertos en el área maya proceden de espacios residenciales. Esta característica cultural, muy específica, complica el proceso de excavación. Pero este aspecto lleva a establecer también un vínculo entre los entierros y la arquitectura, una asociación que permite llegar a una resolución cronológica muy fina para reconstituir la historia de estas residencias y de sus habitantes. En Naachtun (Petén, Guatemala), excavaciones intensivas en el grupo residencial 5N6 durante tres temporadas de campo proporcionaron datos importantes en cuanto a la formación y evolución de un espacio residencial maya antiguo vinculado con las elites locales. Los resultados cuestionan la manera de pensar y de planificar su espacio cotidiano por los habitantes e ilustran la existencia de secuencias funerarias distintas entre los antiguos mayas. [Palabras claves: Antiguos mayas, prácticas funerarias, espacio residencial, secuencia, arqueotanatología.]

La séquence funéraire et architecturale d'un groupe résidentiel maya: le Groupe 5N6, Naachtun, Guatemala. La majorité des contextes funéraires mayas,

* H. Goudiaby: ArchAm (UMR 8096), MSH Mondes, Nanterre, France [ORCID: 00000002-6414-4033] [h.goudiaby@outlook.fr]; P. NoNDÉDÉo: ArchAm (UMR 8096), CNRS, MSH Mondes, Nanterre, France [philippe_nondedeo@yahoo.com].

Journal de la Société des américanistes, 2020, 106-1, p. 19-64. C Société des américanistes. 
du moins ceux identifiés par l'archéologie, proviennent d'espaces résidentiels. Cette spécificité culturelle, tout en compliquant le processus de fouille, établit un lien entre les tombes et les édifices environnants. Cette association permet d'atteindre une très haute résolution chronologique dans la reconstitution de l'histoire de ces résidences et de leurs habitants. À Naachtun (Petén, Guatemala), les fouilles menées dans l'unité résidentielle 5N6 durant trois campagnes successives ont livré des données importantes concernant la formation et l'évolution d'un groupe résidentiel maya associé à l'élite locale. Ces résultats interrogent la manière dont les habitants percevaient et planifiaient leur espace de vie, et mettent en évidence l'existence de plusieurs séquences funéraires chez les Mayas. [Mots-clés : Mayas, pratiques funéraires, espace résidentiel, séquence, archéothatnatologie.]

In the infinitely varied landscape of funerary practices, the ancient Maya certainly hold an unusual place because of their integration of graves into household architecture. As implied by Haviland in his thesis on Tikal's Group 2G-1, and more notably so in his article "Musical Hammocks at Tikal" (see Haviland 1963, 1988, 2014a, 2014b), or by Welsh's synthesis (Welsh 1988, p. 186-200), which has been verified ever since, there exists a tight link between the installation of certain burials and the evolution of the Maya residential space. Such a relationship proves to be extremely informative archaeologically speaking: unlike a cemetery, where accurate contextual data can be difficult to come by, ancient Maya residential burials are surrounded by a wealth of architectural and stratigraphic information. Thus, through sufficiently intensive excavations and an appropriate methodology, it is theoretically possible to reconstruct the building and the funerary sequences at the same time in order to measure if and how they influenced each other, under what conditions and according to what rhythm.

From 2014 to 2016, a specific investigation, part of the Naachtun Archaeological Project (2010-2018) in Guatemala, was dedicated to the study of funerary practices in a small residential patio group ${ }^{1}$ in the residential area that surrounds the epicenter of Naachtun: Group 5N6 (Arredondo Leiva, Goudiaby, and González 2015; Goudiaby, Lacomme, and Schwendener 2016; Goudiaby 2017; Goudiaby 2018, vol. 1). This seven-building patio group was selected according to several criteria:

1. The near-absence of looting, to ensure the discovery of intact funerary contexts.

2. Chronological depth, to allow for a multi-generational analysis; at least two consecutive occupation phases are necessary for the funerary sequence to be relevant. This point was ascertained by a previous test-pitting operation undertaken in 2011 (Cotom, Veliz, and Hernández 2012). 
3. Good preservation of the various residential structures, particularly the stucco floors, in order to guarantee a satisfying stratigraphic assessment. 4. An intermediate-elite group, as can be ascertained by the architectural quality and construction effort (height, relative monumentality). The funerary practices of higher elites are not necessarily representative of the main population. This operation was oriented towards more ordinary, residential practices.

5. Relative isolation. The largest Maya residential groups can include tens of structures and several patios with an extremely complex set of architectural modifications, modified burials and foreign cultural influences. Although by no means uninteresting, such complex cases are not appropriate for time-limited operations given the lengthy nature of intensive and systematic excavations.

This paper is an overview of the results such a funerary-oriented excavation program may yield and offers a discussion of the consecutive problems that arise from it. After a brief history of the question, we present Naachtun's local context and Group 5N6's characteristics and layout. We then present each step of the patio group's history along with individual descriptions of the burials that accompany its architectural transformations. In the last section, we discuss the interpretative implications of the observed practices, notably in terms of the funerary system.

\section{Residential burials in the Maya Lowlands}

The issue of ancient Maya funerary practices was discussed early in the history of the discipline, especially when it came to their association with residential spaces. One of the first observations about ancient Maya funerary customs was made in 1566 when bishop Diego de Landa wrote in his Relación de las Cosas de Yucatán:

They wrapped the dead, filling their mouths with the ground maize they eat and with the drink they call koyem, and with them some of the stones they use for money, so that in the Other World they would not be short of food. They buried them in their house or behind it, and they placed some of their idols in the tomb; and if he was a priest, some of his books; and if he was a sorcerer, his sorcery stones and his weapons. Usually they abandoned the house and left it unoccupied after the burial, except when it housed a lot of people, the company of whom slightly reduced their fear of death. (Landa 1929 [1566], XXXIII, 59) ${ }^{2}$

2. Muertos, los amortajaban, llenándoles la boca de maíz molido, que es su comida y bebida que llaman koyem, y con ello algunas piedras que tienen por moneda, para que en la otra vida no les faltase que comer. Enterrabanlos dentro de sus casas o a las espaldas de ellas, echándoles en la sepultura algunos de sus ídolos; y si era sacerdote, algunos de sus 
As one of the earliest testimonies, Landa's words have often been taken quite literally in archaeology, whether funerary or not.

Haviland's investigations at Tikal are certainly the most notable among the first archaeological studies to specifically address this question (Haviland 1963, 1972, 1985, 1988). Without omitting broader discussions about social structure and ideology (Haviland and Moholy-Nagy 1992), Haviland registered scrupulously the association between the graves and their immediate context. The data extracted from Tikal's Groups 2G-1, 4F-1 and 4F-2 are still among the most exhaustive in this regard, with Tikal Report 19 containing a discussion entitled "Relation of Burials to Construction" along with a table presenting 26 burials associated with various building events, including re-entries (Haviland 1985, p. 150-151). It is one of the first occurrences where this mechanism was duly registered. Tentative interpretations came later; in 1988, Haviland published one of the only models based on a funerary sequence that aimed to explain residential dynamics, without any pretension to universality. This work came after an interesting attempt at palaeodemography that questioned, among other things, population growth patterns and intergenerational relationships among ancient Maya families (Haviland 1972).

Since then, a few works have been dedicated to these dynamics and to the underlying mechanisms, though in many cases they were simply aligned with ancient Maya cultural traits. Chase and Chase (1998) analyzed the architectural context of burials and caches at Caracol, integrating Becker's concept of "earth offerings" (Becker 1993). This context, however, was monumental rather than residential. In northern Belize, McAnany dedicated a great deal of attention to the modest site of K'axob, where she analyzed many aspects of both residential and non-residential funerary practices, with great insight into the site's everyday life (McAnany 1998, 2004, 2013 [1995]). In recent years, at Rio Bec from 2002 to 2010, Pereira conducted some of the most in-depth investigations on residential funerary practices (Pereira 2013). His approach is largely contextual, not unlike Haviland's, but without a predetermined model. It takes into account each burial in its context, diachronically, but also synchronically in relation with the other evolutions of the residential space. The result is a dynamic overview of the funerary sequence, a perspective we adopted for the excavation of Naachtun's Group 5N6.

libros; y si hechicero, sus piedras de hechizo y pertrechos. Comúnmente desamparaban la casa y la dejaban yerma después de enterrados, menos cuando había en ella mucha gente con cuya compañía perdían algo del miedo que les quedaba la muerte. 


\section{Naachtun}

Naachtun is located in northern Petén, Guatemala, approximately $2 \mathrm{~km}$ south of the Mexican border (Figure 1, next page). This localization is of importance, as it is situated only $30 \mathrm{~km}$ south of Calakmul (Mexico) and $70 \mathrm{~km}$ north of Tikal (Guatemala). Early on in its history, Naachtun chose to establish an alliance with the Tikal dynasty shortly before the events of $378 \mathrm{CE}$, which hastened its first apogee (Nondédéo, Lacadena, and Cases 2019). Later on, during the first half of the Late Classic, this center was submitted to the Kanu'l kings of Calakmul (Nondédéo 2017). After its emancipation from this rule around $730 \mathrm{CE}$, Naachtun enjoyed a second apogee that lasted until $950 \mathrm{CE}$. The rediscovery of the city took place during the 1920s, when an expedition of the Carnegie Institution of Washington led by Sylvanus G. Morley entered the monumental epicenter (Morton 2005). The first mapping occurred in 1934 (Ruppert and Denison Jr. 1943), but no real investigations were made at that time. In 2004-2005, a Canadian-Guatemalan project led by Kathryn ReeseTaylor started a series of investigations, establishing the first chronological framework for Naachtun (Rangel and Reese-Taylor 2005). Finally, since 2010, the French-Guatemalan Naachtun Project led by this paper's second author has developed an intensive excavation program and a paleoenvironmental approach that is still in progress.

Naachtun grew along a west-east axis between two seasonal swamps, or bajos, that form natural borders to the north and south (Figure 2, next pages). The monumental epicenter is located atop two limestone eminences that follow exactly the limits of the northern bajo. It was subdivided into three main Groups, labeled A, B and C by the Carnegie Institution (Ruppert and Denison Jr. 1943). Group A seems to be public and/or ritual in nature and dates mainly from the Early Classic. It includes a massive E Group, a ball court and a walled compound that hosted the elite's residences. Group B appears much more like a Late and Terminal Classic residential, elite-controlled area, with a series of private patios organized around two public plazas framed by some minor pyramidal structures and administrative buildings. Finally, Group C, the oldest one, located west of the other two, includes a series of monumental complexes; among them a triadic group and a monumental, heavily looted acropolis that seems to have served funerary purposes for the highest elite during the Early Classic alone. This type of royal funerary context is not unheard of in the region, the closest examples being found at neighboring Tikal, Uaxactun and Rio Azul (Adams 1999; Coe 1990; Loten 2007; Smith 1950). Towards the east, south and west, a vast residential area extends until it meets the natural limit that is the southern swamp and natural drainage channels to the east and west, where the settlement density drops sharply (Lemonnier, Cotom, and Hiquet 2014; Lemonnier and Cotom 2012; Ruppert and Denison Jr. 1943). 
Hemmamuthé GoudiaBy and Philippe NondÉDÉo

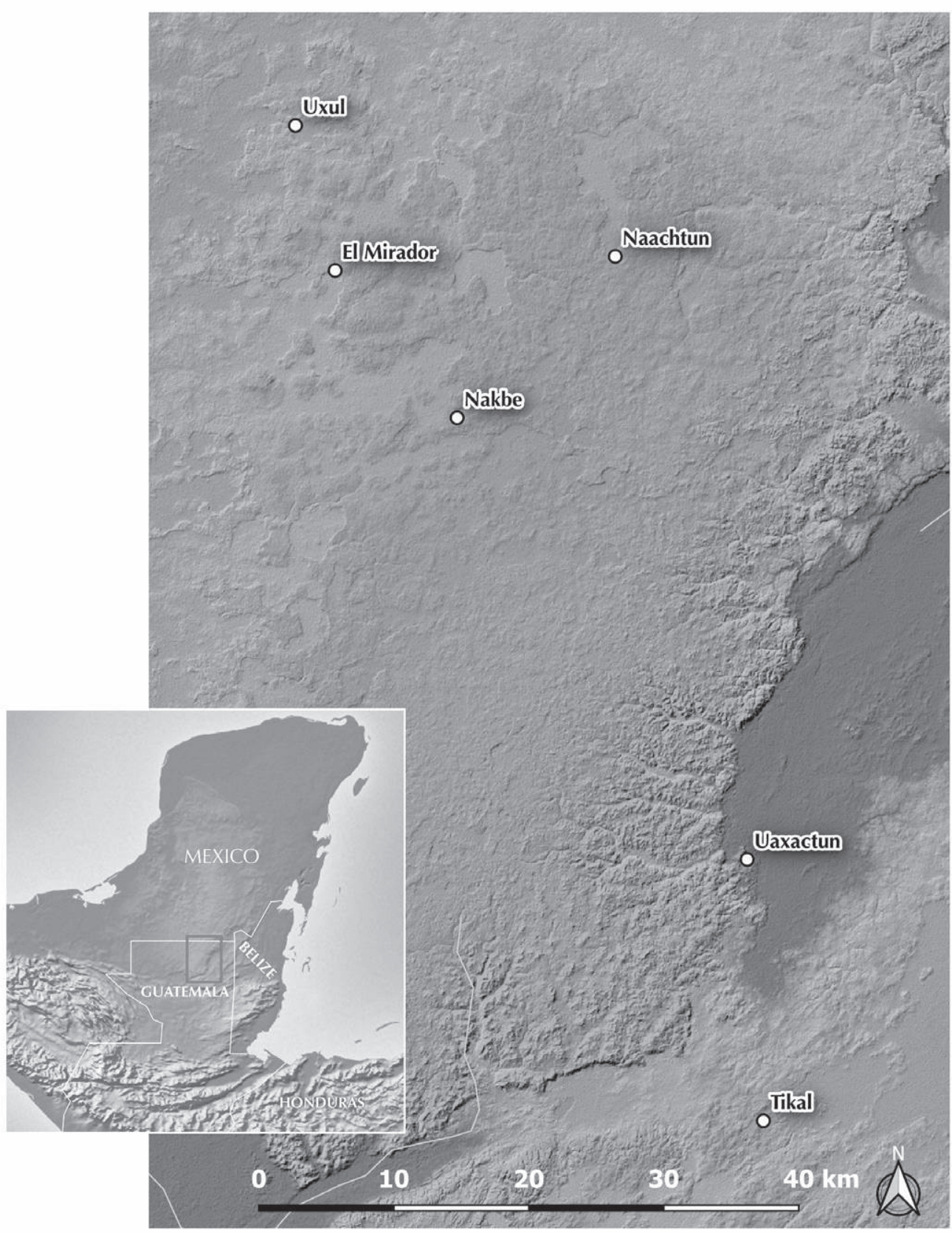

Backgrounds: NaturalEarth v.2 / SRTM 1 arc v.3

Fig. 1 - Map of the Maya area indicating the general location of Naachtun and other important sites in the region (map H. Goudiaby). 


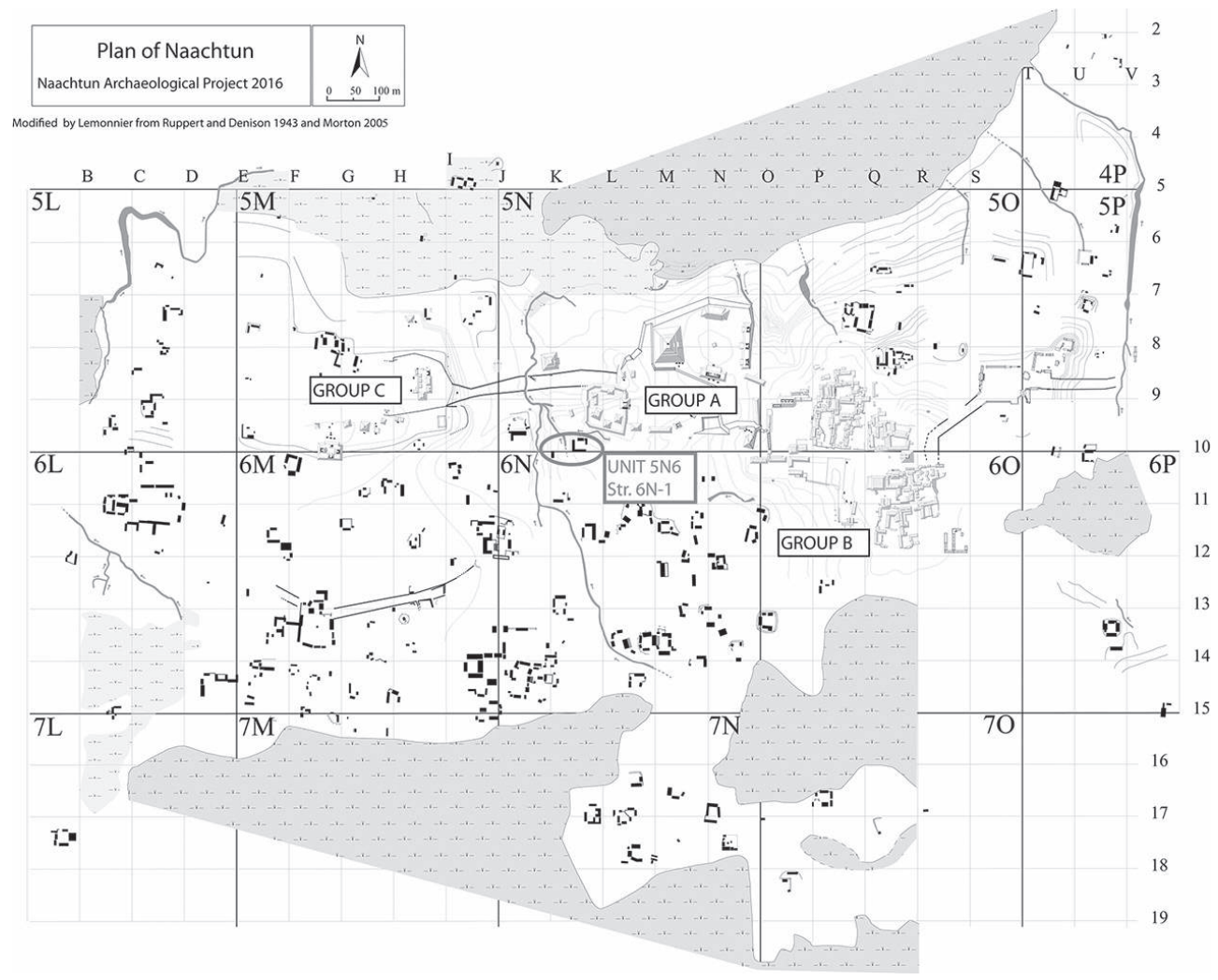

Fig. 2 - Plan of Naachtun indicating the three main Groups, A, B and C, the unit $5 \mathrm{~N} 6$ and the isolated Structure $6 \mathrm{~N}-1$

(map modified by H. Goudiaby after E. Lemonnier).

Naachtun's first occupations are anchored in the Late Preclassic (Table 1), although at this time the city was probably little more than a modest hamlet with dispersed domestic units (Nondédéo et al. 2013, p. 125; Rangel and ReeseTaylor 2005; Hiquet 2019). At the beginning of the Early Classic period, what was a period of steady growth turned into one of important expansion - a direct consequence, perhaps, of Naachtun's implication in bigger historical events, most notably a military alliance with Siyaj K'ah'k, recorded on stela 24 (Cases and Lacadena 2015, p. 378; Nondédéo, Lacadena, and Cases 2019). This role on the regional scene maintains itself during the Late and Terminal Classic and manifests through an apparent material prosperity (Nondédéo 2017; Nondédéo et al. 2012, in press; Patiño-Contreras 2016, p. 4; Sion 2016). 


\begin{tabular}{|c|c|c|c|}
\hline Chronology & Phase name & Sub-phases & Dates \\
\hline \multirow{2}{*}{$\begin{array}{l}\text { Terminal Classic/ } \\
\text { Early Postclassic }\end{array}$} & \multirow[t]{2}{*}{ Muuch } & 2 & $\begin{array}{c}\text { 900/950- } \\
1100 / 1200 \mathrm{CE}\end{array}$ \\
\hline & & 1 & $830-900 / 950 \mathrm{CE}$ \\
\hline \multirow{3}{*}{ Late Classic } & \multirow{3}{*}{ Maax } & 3 & 750-830 CE \\
\hline & & 2 & 650-750 CE \\
\hline & & 1 & 550-650 CE \\
\hline \multirow{3}{*}{ Early Classic } & \multirow{3}{*}{ Balam } & 3 & 400-550 CE \\
\hline & & 2 & 300-400 CE \\
\hline & & 1 & 150-300 CE \\
\hline $\begin{array}{c}\text { Late/Terminal } \\
\text { Preclassic }\end{array}$ & Kut's & none & $?-150 \mathrm{CE}$ \\
\hline
\end{tabular}

Table 1 - Naachtun's ceramic sequence (Hiquet, Sion, and Perla-Barrera in press).

\section{Group 5N6}

\section{General context}

Group 5N6, ${ }^{3}$ named after its northern Structure 5N-6, which was considered the most important during the survey, is situated $30 \mathrm{~m}$ immediately southwest from Group A's walled compound, a top elite residential complex used from the Early Classic to the Late Classic Period (Arredondo Leiva 2010) (Figure 2). Group 5N6 is physically separated from it by a topographical accident to the north in the form of a 5-m-deep, narrow talweg running from east to west towards a channel that communicates with the northern swamp. In ancient times, it would have been impossible to walk directly from the walled compound to Group 5N6, and the presence of the talweg justifies 5N6's inclusion among the settlement units of the residential area. As expected, this unit does not have any access on this side, but is simply delimited by a crude platform that supports seven structures (Goudiaby 2017), disposed most irregularly around a rectangular central courtyard (Figure 3 ). The buildings have been numbered from 5 to 9 clockwise, starting from the west. Westward, Group 5N6 is bordered by another steep slope that connects with the talweg to the northwest. The only flat terrain in the immediate vicinity extends to the south, southeast and southwest, where a vacant space stretches for more than $100 \mathrm{~m}$. This space could have been used for infield agriculture or horticulture (Purdue 2018; Purdue and Goudiaby 2017). A significant exception in this sector is the presence of an

3. To distinguish between residential patio groups and structures, patio group names are written without a dash (e.g. Group 5N6) while structures are written according to a square $\mathrm{n}^{\circ}$-cypher nomenclature (e.g. Structure 5N-6). 


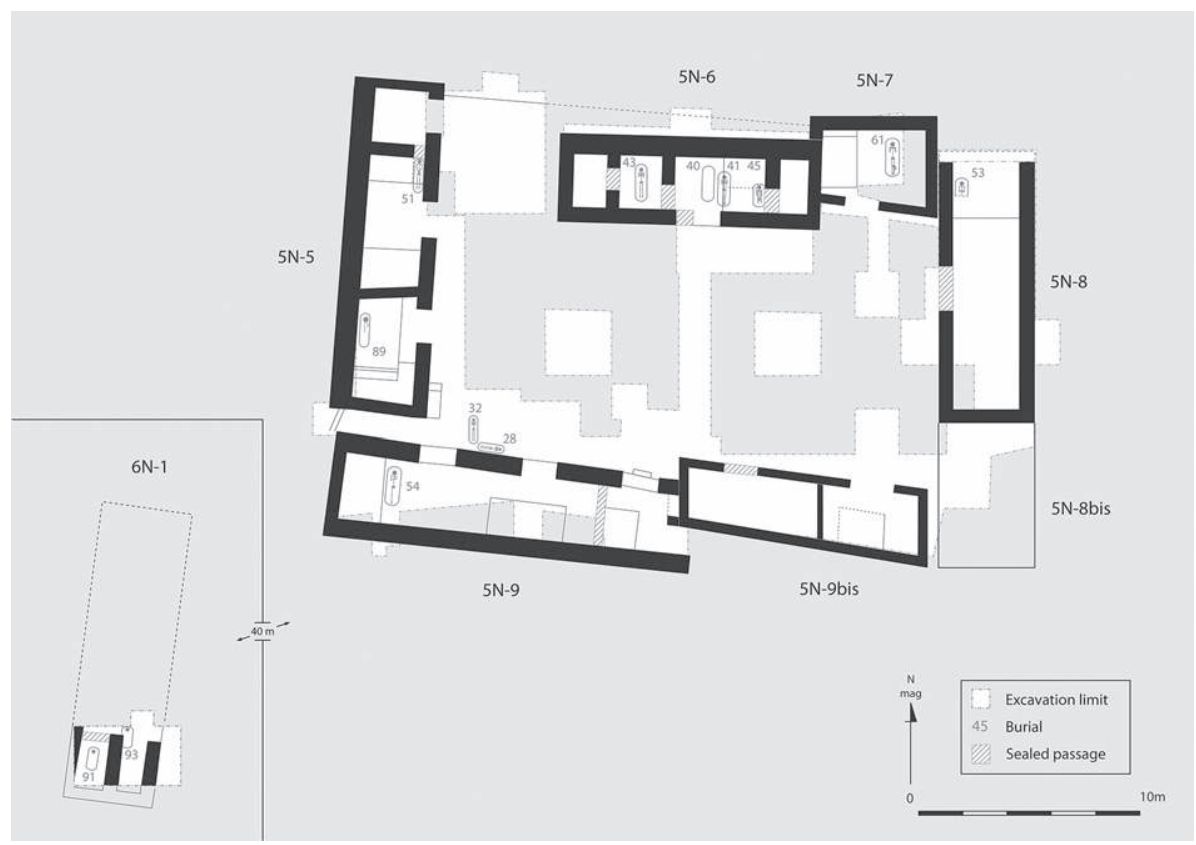

Fig. 3 - Plan of the Unit 5N6 and Structure $6 \mathrm{~N}-1$ showing the location of the burials and the limits of the excavation (plan H. Goudiaby).

isolated structure, $6 \mathrm{~N}-1$, located $40 \mathrm{~m}$ west-southwest from the main unit and that could have functioned with it.

The material culture suggests that the inhabitants were not simple commoners, but neither did they pertain to the highest levels of the elite. They were probably part of intermediate elites involved in artistic production for higherranking households or individuals, as indicated by the presence of two painting palettes discovered on the floor in Structure 5N-9-bis (Goudiaby, Lacomme, and Schwendener 2016, p. 210), a small shell cup with traces of red hematite pigment, and by the discovery of a limestone jade polisher in Structure $5 \mathrm{~N}-8$ used for earspools and bead manufacturing (Andrieu 2016, p. 353). To this we may add the relatively high frequency of shell ornaments and fragments of polychrome ceramic drums, a profile that is similar in nature, if not in quality, to that of the House of the Scribe at Aguateca (Inomata 2001).

\section{Excavation method}

The excavation of Group 5N6 followed a precise procedure. After establishing a cardinally oriented grid, every structure was completely exposed without omitting any room or wall. The floors and benches were systematically test-pitted 
down to the bedrock in search of burials, permitting at the same time an exhaustive stratigraphic and architectural record. In the courtyard, a series of trenches and test pits were conducted following the same method. Only the fills of the two rooms in Structure 5N-9-bis were left unexplored owing to lack of time. This intensive excavation was decided upon in order to lessen the impact of methodology on the number of burials to be discovered by avoiding as much as possible trenches and narrow spaces/superficial excavations (Goudiaby 2019). The final excavated area covers 406 sq. m, which represents $57 \%$ of the total area of the patio group ( $710 \mathrm{sq}$. $\mathrm{m}$ ). The excavation depth varies from 1 to $3 \mathrm{~m}$ in the central courtyard, and averages $1.50 \mathrm{~m}$ beneath the buildings before reaching bedrock. In order to check the possible association between Group 5N6 and Structure $6 \mathrm{~N}-1$, we initially decided to explore $6 \mathrm{~N} 1$ under the same parameters. However, time constraints forced us to explore only its southern half, by the way of a single 5-m-long and 3-m-wide east-west trench in which two additional test pits were excavated. Regarding chronology, we opted for relative stratigraphy through the use of Harris matrixes (Harris 1979), along with ceramic typology ${ }^{4}$ and radiocarbon dates (Tables 1,2).

In total, this intensive work allowed us to expose 13 burials: 11 in Group 5N6 and two more in Structure 6N-1 (Figure 3, Table 3). All of these burials were excavated according to the principles of archaeothanatology, formalized by Henri Duday and colleagues from the end of the 1970s to the early 1990s (Duday 2009; Duday et al. 1990). Archaeothanatology is a composite approach to mortuary contexts that combines archaeological, taphonomic and biological data. It is a holistic, high-resolution process that aims to reconstitute accurately individual stories and chains of events before integrating them in a bigger picture. Contextual data and human taphonomy are key to this endeavor. In such contexts as ancient Maya residential compounds, the stratigraphy often yields valuable clues as to when and how burials were installed. A rigorous assessment of interosseous relationships is also integral to this approach. Indeed, in addition to the decomposition process itself, the movements of the bones may be influenced by various factors, natural (gravity, climate, animals, root actions...) as well as intentional and/or unintentional anthropic ones (gutting, wrapping, deposition of ashes and/or perishable grave goods, backfilling...). ${ }^{5}$ Once identified, all these details lead to a general comprehension of the mortuary practices as a whole. Outstanding examples of such an approach in the Maya area came from Pereira's studies at Balamku and Rio Bec (Pereira and

4. All determinations by Dr. Alejandro Patiño-Contreras with contributions from Julien Sion and Divina Perla Barrera.

5. For in-depth discussions, see, for instance, Duday 2009, Mickleburgh and Wescott 2018, Micozzi 1991, Peressinotto 2007. 
The funerary and architectural history of an ancient Maya residential group

\begin{tabular}{|c|c|c|c|c|c|}
\hline SU/Burial & Lab $n^{0}$ & Sample nature* & Age BP & $\begin{array}{l}\text { Age cal. CE } \\
\quad(95 \% \\
\text { probability) }\end{array}$ & $\begin{array}{l}\text { Associated } \\
\text { ceramics** }\end{array}$ \\
\hline 2965 & Lyon-12474 & $\begin{array}{c}\text { Charcoal } \\
\text { Myrtaceae- } \\
\text { Eugenia } \text { sp. }\end{array}$ & $1615 \pm 30$ & $387-538$ & Balam 3 \\
\hline 2783/BU 41 & Lyon-12475 & $\begin{array}{c}\text { Charcoal } \\
\text { Fabaceae- } \\
\text { Lonchocarpus } \\
\text { sp. }\end{array}$ & $1340 \pm 30$ & $645-765$ & Maax 2 \\
\hline 2759/BU 43 & Lyon-12476 & $\begin{array}{c}\text { Charcoal } \\
\text { Poaceae } \\
\text { - Bambusoideae }\end{array}$ & $1265 \pm 30$ & $666-863$ & Maax 3 \\
\hline 2776/BU 45 & Lyon-12477 & $\begin{array}{c}\text { Charcoal } \\
\text { Ebenaceae- } \\
\text { Diospiros sp. }\end{array}$ & $1325 \pm 30$ & $650-768$ & Maax 2 \\
\hline 4691/BU 53 & $\begin{array}{c}\text { Groningen } \\
-17390\end{array}$ & $\begin{array}{c}\text { Human } \\
\text { longbone } \\
\text { (undetermined) }\end{array}$ & $1440 \pm 25$ & $576-651$ & $\begin{array}{c}\text { Balam 3- } \\
\text { Maax } 1\end{array}$ \\
\hline $\begin{array}{c}5125 / \\
\text { BU 61A }\end{array}$ & $\begin{array}{c}\text { Groningen } \\
-17391\end{array}$ & $\begin{array}{c}\text { Human right } \\
\text { tibia }\end{array}$ & $1255 \pm 20$ & $676-776$ & Maax 3 \\
\hline
\end{tabular}

Table 2 - Radiocarbon dates from Structure 5N-6 (H. Goudiaby).

*Wood charcoals identification by Lydie Dussol.

** Determination by Alejandro Patiño, Julien Sion and Divina Perla Barrera.

Michelet 2004; Pereira 2013), Tiesler's at Xuenkal (Tiesler et al. 2010), and more recently from Novotny's in the Belize River Valley (Novotny 2015).

Poor preservation of the bones did not allow for the use of probabilistic sex diagnosis (DSP, Brůžek et al. 2017; Murail et al. 2005), and this method was replaced, when appropriate, by Wrobel's discriminant function analysis and Brůžek's visual method (Brůžek 2002; Wrobel, Danforth, and Armstrong 2002). They proved to be rather effective considering Naachtun's considerable sexual dimorphism. As for the determination of the age at death, the method used will be mentioned, as appropriate, in the burials' description. It must also be mentioned that, for general preservation reasons, Burials 28, 32, 89 and 91 will not be described here ${ }^{6}$ (but see Cotom, Veliz, and Hernández 2012; Goudiaby 2017, p. 205-207; Goudiaby 2018, vol. 1, p. 328-329).

6. Burials 28 and 32, in addition to severe damage due to the stony sediment, were excavated before the first author's works in Group 5N6 and have not been subjected to an exhaustive taphonomical study but only to a laboratory analysis. BU 32 has been found beneath the deepest floor of the patio and belongs to a child (2-3 years old) laid E-W. All the evidence suggests a founding context. By contrast, BU 28 was installed later, by 


\begin{tabular}{|c|c|c|c|c|c|c|c|}
\hline $\mathbf{N}^{0}$ & Structure & Sex & $\begin{array}{c}\text { Age } \\
\text { range* }\end{array}$ & Position** & Orientation & Deposit & Phase \\
\hline $28+$ & Patio & - & $5-9$ & D.d. ?/e & E-W & Primary & Maax \\
\hline $32+$ & Patio & - & $1-4$ & D.d. ?/e & $\mathrm{N}-\mathrm{S}$ & Primary & Balam? \\
\hline 40 & $5 N-6$ & - & - & - & - & - & Maax 2? \\
\hline 41 & $5 \mathrm{~N}-6$ & M & $\begin{array}{c}\text { Middle- } \\
\text { aged } \\
\text { adult }\end{array}$ & D.d. f/e & N-S & Primary & Maax 2 \\
\hline 43 & $5 \mathrm{~N}-6$ & F? & Adult & D.d. f/e & $\mathrm{N}-\mathrm{S}$ & Primary & Maax 3 \\
\hline 45 & $5 N-6$ & M & $\begin{array}{c}\text { Middle- } \\
\text { aged } \\
\text { adult }\end{array}$ & D.d. $\mathrm{f} / \mathrm{f}$ & $\mathrm{N}-\mathrm{S}$ & Primary & Maax 2 \\
\hline 51 & $5 \mathrm{~N}-5$ & F? & Adult & D.d. sf/e & $\mathrm{N}-\mathrm{S}$ & Primary & Maax 2 \\
\hline 53 & $5 N-8$ & - & $\begin{array}{c}\text { Middle- } \\
\text { to-aged } \\
\text { adult }\end{array}$ & D.d. f/? & N-S & Primary & $\begin{array}{l}\text { Balam } 3 \\
\text {-Maax } 1\end{array}$ \\
\hline 54 & $5 N-9$ & - & Adult & D.d. f/e & $\mathrm{N}-\mathrm{S}$ & Primary & Maax 1-2 \\
\hline $61 \mathrm{~A}$ & $5 \mathrm{~N}-7$ & $\mathrm{~F}$ & $\begin{array}{c}\text { Middle- } \\
\text { aged } \\
\text { adult }\end{array}$ & D.d. f/e & N-S & Primary & Maax 3 \\
\hline $61 \mathrm{~B}$ & $5 \mathrm{~N}-7$ & - & $1-4$ & L.r.D. f/f & $\mathrm{N}-\mathrm{S}$ & Secondary & Maax 3 \\
\hline $89+$ & $5 N-5$ & - & Adult & D.d. ?/? & N-S & - & $\begin{array}{c}\text { Maax } \\
\text { (Looted) }\end{array}$ \\
\hline $91+$ & $6 \mathrm{~N}-1$ & - & - & - & $\mathrm{NsS}$ & Primary & Maax 3 \\
\hline 93 & $6 \mathrm{~N}-1$ & - & $\begin{array}{c}\text { Middle- } \\
\text { to-aged } \\
\text { adult }\end{array}$ & - & - & Secondary & Maax 2 \\
\hline
\end{tabular}

Table 3 - Individual and contextual data for 5N6 and 6N-1 (H. Goudiaby).

* Age ranges are: 0 (perinatal)/1-4/5-9/10-14/15-19/young adult (20-30)/middleaged adult (30-50)/aged adult $(>50)$.

** D.d. $=$ dorsal decubitus 7 L.r.D. $=$ Lateral right decubitus $/ \mathrm{f}=$ flexed/ $\mathrm{sf}=$ semi-flexed $/ \mathrm{e}=$ extended.

The first letter indicates the superior members, the second the inferior ones. $\$$ Nondescript in the article.

perforating the four patio floors present in this area. It corresponds to an N-S burial of a child (4-7 years old) and belongs to an occupation context (Barrientos Juárez 2012, p. 233; Patrois and Nondédéo in press). In Burials 89 and 91, skeletal remains were nearly absent, and both had been heavily disturbed by the roots. In the case of Burial 89, a small looting trench increased the damage.

7. Decubitus, from Latin decumbere, "lying," is a medical term describing a recumbent body and is commonly used to describe the position of the skeleton compared to a horizontal plan. The decubitus can be dorsal, lateral or ventral. In the latter case, procubitus is also employed. 


\section{The building and burial sequence}

The concomitant evolution of architectural and funerary sequences is the most original aspect of ancient Maya mortuary behaviors. In order not to isolate the burials from their context, which would be detrimental, we opted to present both sequentially (Figure 4, next page). For each phase, new buildings and transformations of older ones will be described, followed by the associated burials in chronological order. We will also consider the radiocarbon dating sequence, which is helpful for analyses and interpretations (Figure 5, next pages). This dynamic picture of Group 5N6's history will establish the baseline for our final discussion.

\section{Balam 2 (AD 300-400)}

The very first occupation at the Group $5 \mathrm{~N} 6$ locus is poorly understood, and its general aspect remains largely theoretical (Goudiaby 2018, vol. 1, p. 206-208). The deepest excavated test pits always reveal the same sequence: sealed beneath the Balam 2 levels, a thick layer of perfectly leveled black organic clay extends down to the bedrock (Arredondo Leiva, Goudiaby, and González 2015; Cotom, Veliz, and Hernández 2012, fig. 15). We now know that these black organic soils were present in different parts of the city, below Late Classic residential complexes in Group B and below Group A's main plaza. They represent the first cultivated spaces "downtown" before the building of the monumental epicenter (Purdue et al. 2016). Bedrock in 5N6 is very irregular, especially on the west, where it is so shallow in some places that Structure $5 \mathrm{~N}-5$ has been partly built directly over it. Given that the leveled clay appears in every excavated test pit, but is obviously of exogenous origin, it is also probably part of the original terracing effort that required flat, regular ground to build upon.

The only building we know of for this phase is a substructure that occupied the northern edge of the unit, Structure 5N-6-Sub. It appeared in a vast test pit located in the central room of Structure $5 \mathrm{~N}-6$, where the floor has been entirely removed during the excavation. One meter below the level of Structure 5N-6, the red-painted plaster floor of this earlier construction appeared. Two postholes in this floor indicate that Structure 5N-6-Sub was a perishable building on a basal platform (Goudiaby, Lacomme, and Schwendener 2016, p. 200). Although no burial marks this first occupation, a deposit consisting of an inverted polychrome bowl, a small jar and a whistle figurine (ocarina) representing a fantastic zoomorphic creature was discovered near the northeastern corner of the room (Figure 6, next pages).

\section{Balam 3 (AD 400-550) and the Structure 5N-6-Sub hiatus}

The history of Structure 5N-6-Sub ended abruptly during the Balam 3 phase, when the house was entirely destroyed. Only the basal platform remained; this 

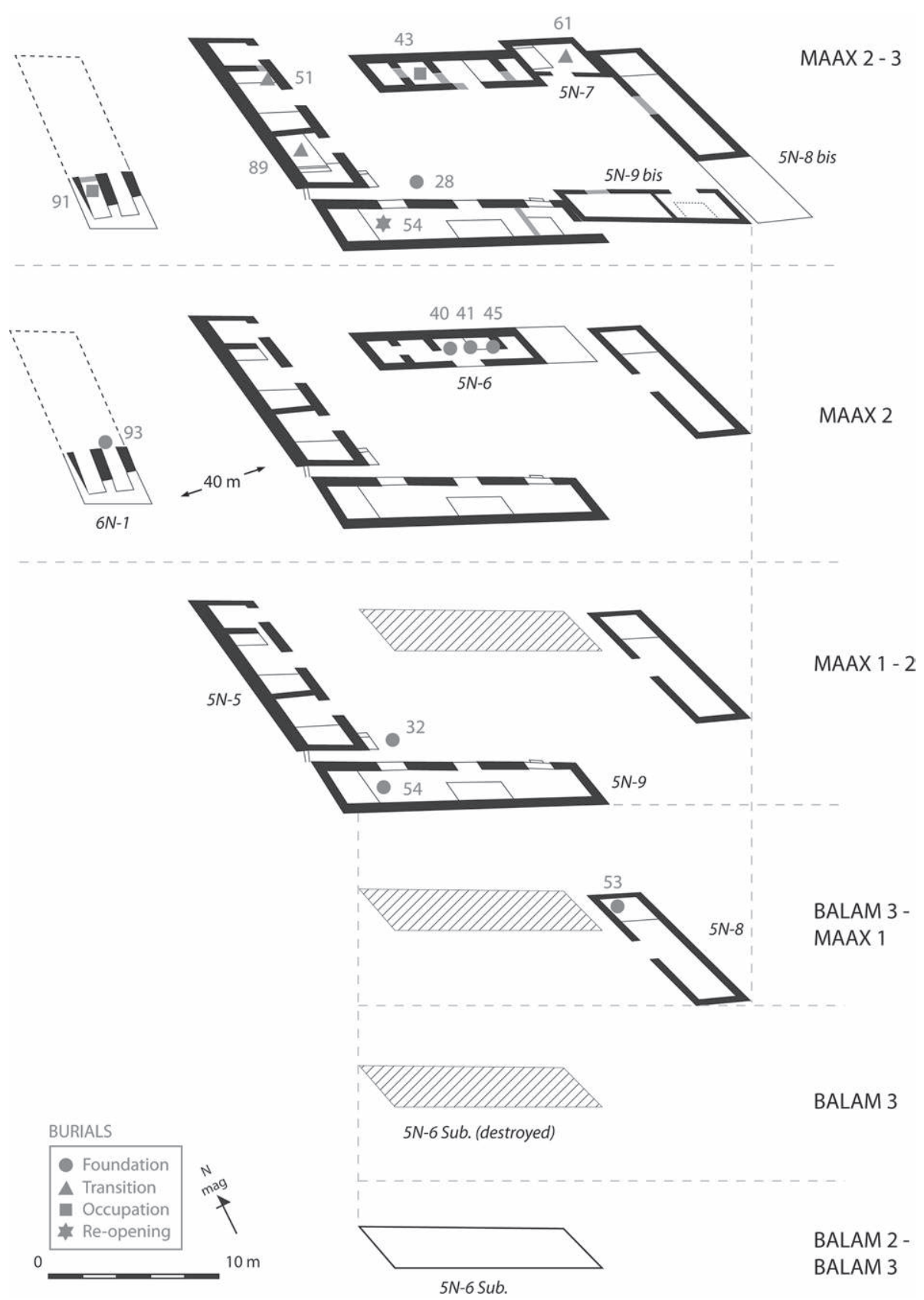

MAAX $1-2$

Fig. 4 - Architectural evolution of the Group 5N6 correlated with the funerary sequence, showing the different categories of burials.

Gray walls on the last step indicate sealed doors (plan H. Goudiaby). 
The funerary and architectural history of an ancient Maya residential group

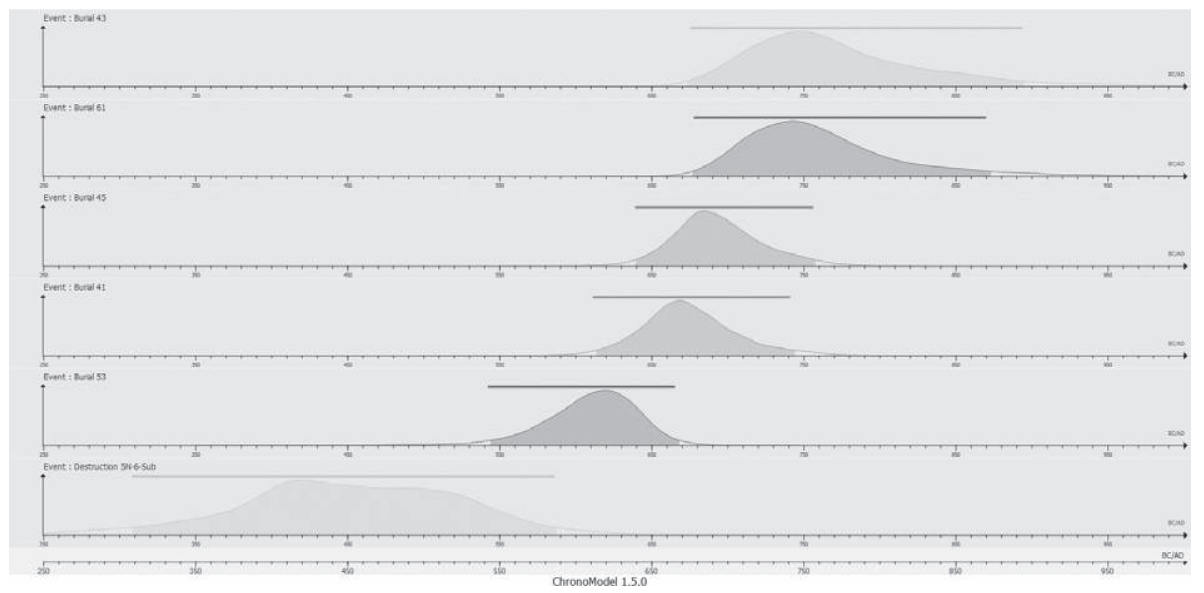

Fig. 5 - Chronological occupation model of Group 5N6 according to the radiocarbon dates processed with ChronoModel 1.5.0. Despite the poor

resolution of the most ancient date, the existence of a hiatus between the event it marks and the first burial (53) is near-certain (H. Goudiaby).

○
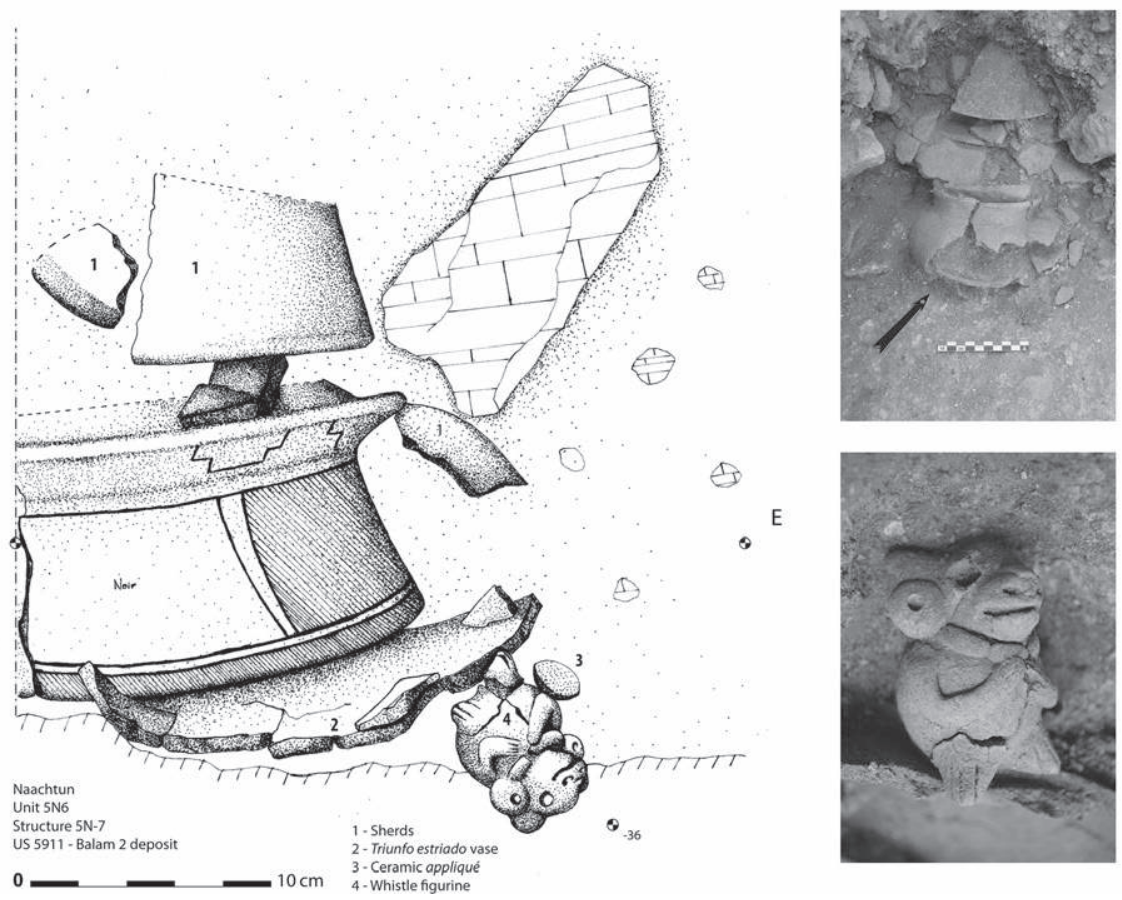

Fig. 6 - Deposit under the first structure on Group 5N6's locus.

Note the inverted whistle figurine on the east. This disposition is probably intentional, considering that it was stuck in this position by the ceramics above and the construction fill (drawing and photograph H. Goudiaby). 
event was observable through the presence of an ashy layer, about $40 \mathrm{~cm}$ thick, which sealed entirely the lower levels and appeared in every test pit dug beneath the northern structures (5N-6 and 7). Fragments of several ceramic vessels from the Balam 3 ceramic complex were scattered on its surface, and sherds discovered in distant test pits proved to pertain to the same vessels, implying an in situ termination ritual event with breakage of ceramic dishes and dispersal of the sherds (see Newman 2019 for a recent overview on this topic). At the western limit of the layer, below the westernmost room of Structure 5N-6, a concentration of charcoal indicated that a fire had been lit in situ after the house was demolished (Arredondo Leiva, Goudiaby, and Gonzalez 2015, p. 247). A radiocarbon date from this concentration indicates the event took place somewhere between 387 and 538 cal. CE (Lyon-12474, Table 2). This chain of events recalls small-scale termination events observed elsewhere (e.g. Lucero 2003, p. 531).

No material from the Maax 1 facet has been identified in Structure 5N-6 (but it is worth noting that, to this day, the distinction between ceramics types and forms from the Maax 1 and 2 facets remains difficult). According to the ceramic analysis and radiocarbon dates, it seems clear that there was a hiatus between Balam 3 and Maax 2 for this building. It is even possible that Group 5N6 was totally abandoned for a time during part of Balam 3, before the construction of Structure $5 \mathrm{~N}-8$. If true, the duration of this vacancy is difficult to determine, but according to the model (Figure 5, blue event) it could easily exceed 50 years. This point remains obscure and will require more investigations. Indeed, an interesting question is that of the relationship between the people who occupied this area initially and those who came later. They could pertain to unrelated families, or be descendants coming back to their roots (see Burial 53, below). What is certain is that the return of inhabitants, from the same family group or unrelated, triggered an intensive construction period that began with one first, physical anchor: Burial 53.

\section{Balam 3-Maax 1 (AD 550-650)}

The Balam 3-Maax 1 transition is the beginning of a rapid growth for Group 5N6. Its dimensions remain quite modest, with only one structure on the eastern side of the patio, Structure $5 \mathrm{~N}-8$. Nevertheless, the important dimensions of this new building and the quality of grave goods in its associated burial give a hint of the times to come.

\section{Structure $5 \mathrm{~N}-8$}

Structure $5 \mathrm{~N}-8$ is the first stone-built residence in the unit and does not seem to have been vaulted. Its dimensions as a living space are considerable: $2.80 \mathrm{~m}$ wide by $10 \mathrm{~m}$ long, with a $2.30 \times 2.80 \mathrm{~m}, 60$-cm-high lateral bench occupying 
the northern side of the room (Goudiaby, Lacomme, and Schwendener 2016, p. 200-201). A single, central door on the western side gave access to this vast room, which did not present any visible internal division. In this context, Burial 53 was not located on the main axis of the structure but beneath the bench, along the western wall. The plaster floor sealed it and the bench did not show any evidence of intrusion, which firmly establishes Burial 53 as a foundation burial from which Structure $5 \mathrm{~N}-8$ was born. There is no evidence of other constructions in the unit for this transitional phase, and a test pit excavated at the center of the room reached the black clay level without showing any anterior construction.

\section{Burial 53: the eldest (Balam 3-Maax 1)}

Burial 53 is a cist located below the northern bench (Figure 7, next page). It is the only one known for this building; it has not been possible to determine the sex of this individual, whose remains are badly destroyed by the roots. The presence of ossified thyroidal cartilage suggests a middle-to-aged adult (Goudiaby, Lacomme, and Schwendener 2016, p. 206; Goudiaby 2018, vol. 1, p. 271-274). The body was laid on its back, head to the north, forearms crossed on its chest, which is Naachtun's standard practice. A perforated plate covered its face, accompanied by a cylindrical vase and a miniature bottle. Despite the damage withstood, it was possible to determine that the skull presented a slight tabular erected deformation (Tiesler 1999, p. 207).

This burial becomes particularly interesting in terms of sequence when coupled with the aforementioned Balam 3 hiatus. Indeed, the age at death of this individual is advanced enough to suggest they were a child when Structure $5 \mathrm{~N}-6-\mathrm{Sub}$ was destroyed, if the destruction took place late. We know that the termination event occurred during the 387-538 CE interval; individual 53 died in the 576$651 \mathrm{CE}$ interval (Groningen-17390, Table 2). The dates are not precise enough to be affirmative and probabilities are quite low, but it is nonetheless interesting to envision the possibility of a person coming back to where they were born to found a new residential space there, or wishing to be buried at their birthplace and being interred beneath a new building by their offspring. The likeliest scenario, however, is that the hiatus was too long for a direct relationship to exist between Structure 5N-6-Sub inhabitants and the new occupation that starts during Maax 1.

\section{Maax 1-2 (AD 550-750)}

The Maax 1-2 phase witnesses the construction of nearly all of the buildings in Group 5N6. Interestingly, this sudden growth that finds its origin in Maax 1 does not correspond to the overall expansion of the site's residential area but to the local dynamism of Group 5N6. 

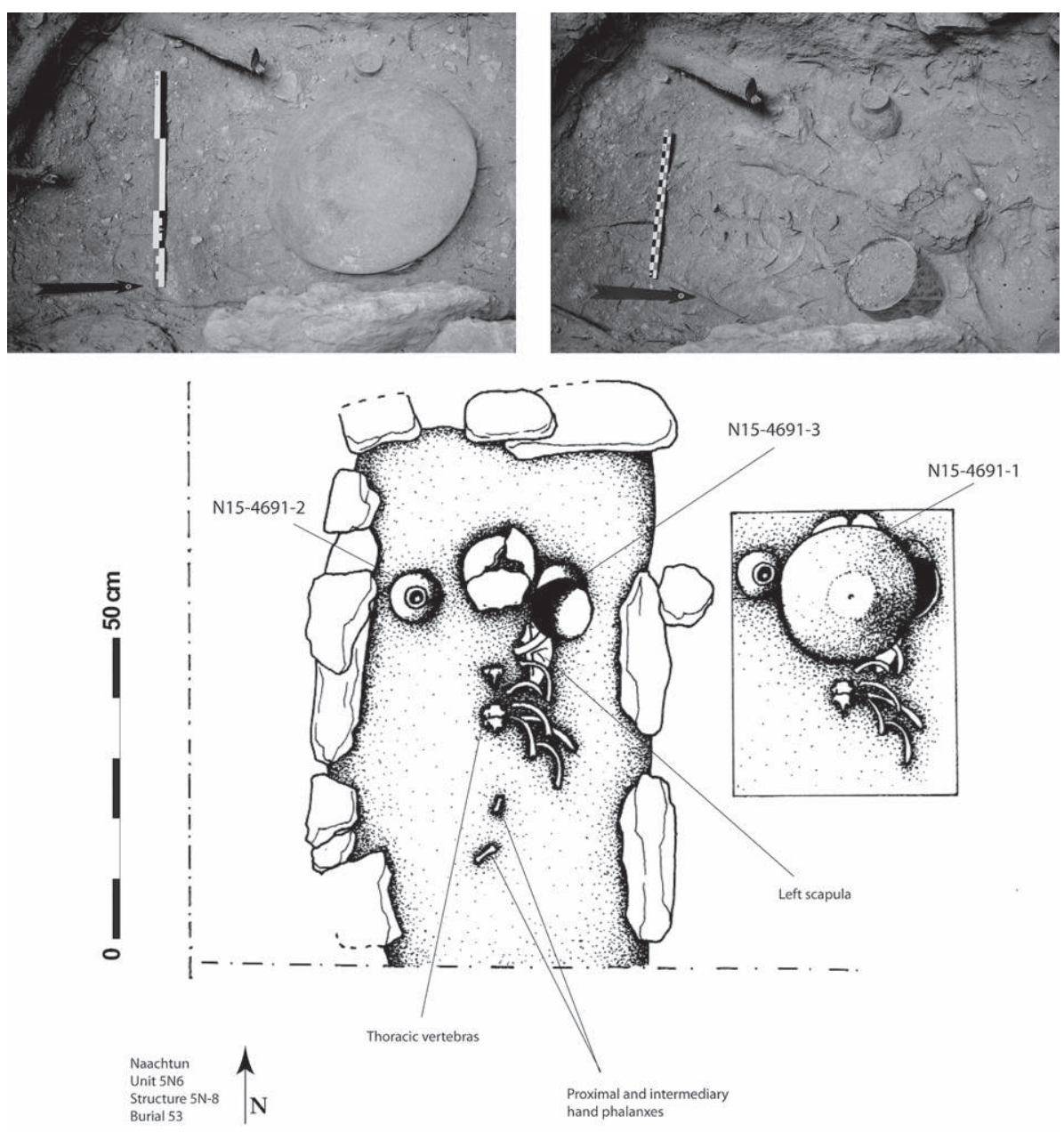

Fig. 7 - Drawing and photographs of Burial 53, the oldest one of the compound. Root activity destroyed most of the bones, but the general position of the subject remains discernible (drawing and photographs H. Goudiaby).

\section{Structure 5N-5}

During Maax 1, Structure 5N-5 appears on the west side of the unit. The construction fill within the benches and below the floors contained only Maax sherds, and no substructure was found during the excavation, suggesting Structure 5N-5 was built shortly after Structure $5 \mathrm{~N}-8$. This $15-\mathrm{m}-$ long rectangular, three-roomed and vaulted residence stood on a platform that compensated for the western slope and rested partly on the bedrock (Arredondo Leiva, Goudiaby, and González 2015; 
Goudiaby, Lacomme, and Schwendener 2016, p. 187). The northern room was littered with ashes, potsherds, chert and snail fragments, as well as burnt corn (Arredondo Leiva, Goudiaby, and González 2015, p. 256). These clues point to a storage room and/or a cooking area. Structure $5 \mathrm{~N}-5$ does not have any associated burial with its first stage, but later on, during Maax 3, ${ }^{8}$ Burial 51 was installed in a narrow passageway that connected the central room with this supposed storage area (see below).

\section{Structure 5N-9}

On the southwestern corner of the courtyard, at about the same time Structure $5 \mathrm{~N}-5$ was built, construction of residence $5 \mathrm{~N}-9$ started. This building is also anchored by a burial, BU 54, which was put in place according to a rather unique sequence that we shall discuss below. Structure $5 \mathrm{~N}-9$ looks very similar to its immediate neighbor: a rectangular 18 -m-long by $3.40-\mathrm{m}$-wide building, with three doors regularly distributed. It was not vaulted. The central door opened directly on an axial bench, while a lateral one, near BU 54, occupied the westernmost edge of this vast undivided room. During the Maax 1-2 phase, Structure $5 \mathrm{~N}-9$ is the only building to present such a configuration, which could indicate that, at this time, it served as a reception area.

Burial 54: the corn and the re-entry (Maax 1-2)

This burial, slightly later than Burial 53 (Patiño-Contreras 2016, p. 343), was located at the foot of the west bench, far from the door's axis (Goudiaby, Lacomme, and Schwendener 2016, p. 207; Goudiaby 2018, vol. 1, p. 302-307). It was visible from the ground in the form of a low stone mound emerging above the destroyed floor level and indicating a late intrusion into the tomb. It is actually the only burial in Group 5N6 whose history marks at the same time the beginning and the end of a building's occupation.

Originally, Burial 54 was a cist dug in the rubble fill of 5N9 platform during the first building effort. The individual lays on his back, legs extended, arms folded on his chest. The capstones were covered by a 5-cm-thick layer of burnt vegetal material; soil samples from this layer revealed that it was entirely constituted of burnt ears of corn (Dussol 2016, p. 427). The association of corn with mortuary contexts is not surprising given its symbolic value; it is especially linked with death and rebirth (Fitzsimmons 2009, p. 21-25).

The burial was then re-entered during Maax 3, most probably to recover the left leg's long bones: although the skeleton was poorly preserved, fragments of the left femur and tibia were utterly missing. The intrusion that led to the grave

8. Burial 51 was formerly attributed to the end of the Maax 2 phase in previous works, but a re-examination of the accompanying wares makes a relation to Maax 3 more likely. 
was not located exactly above the burial, but $1 \mathrm{~m}$ to the east. It partly destroyed the eastern wall of the cist. Assuming our chronology is correct, we can place the inhumation between 550 and $740 \mathrm{CE}$, most probably 550-650 CE if ceramics are to be trusted. The floor, on the other hand, was not repaired after the grave's reopening. This event must have taken place between 740 and $830 \mathrm{CE}$, when the last inhabitants left the unit. The minimal duration between burial and reopening is thus estimated at 90 years.

\section{Structure 5N-6}

On the northern edge of the Group, no rebuilding took place until Maax 2 and the erection of Structure 5N-6. It adopted the form of a vaulted, 11-m-long and 2.30-m-wide building divided into four rooms with a single entrance in the central one. The doorway leads to a square room with a very unusual lateral bench in the northeast corner. The most prominent characteristic of this stage is the presence of three burials that were disposed directly beneath this central room and below the bench: Burials 40, 41 and 45 (Arredondo Leiva, Goudiaby, and González 2015, p. 85-88; Goudiaby 2018, vol. 1). The plaster floor above the three graves was intact, and we have to assume they were buried more or less at the same time on the locus of former Structure 5N-6-Sub, before the construction of Structure 5N-6's floor and bench. Among this set of burials, Burial 40 poses a particularly challenging problem: it was found empty, or had been emptied. Burials 41 and 45 yielded two similar radiocarbon dates, respectively 645-765 CE and 650-768 CE (Lyon-12475 and 12477, Table 2). Cross-compared with the funerary goods (see Burial 45 below), this range can be reduced to 645-740 CE for the burial of these individuals and, most likely, the building of Structure 5N-6.

\section{Burial 40: the missing dead (Maax 2)}

Burial 40, a cist, was invisible from the surface. It was located on the doorway's axis. The grave was entirely filled with $s a s c a b$, a white powdery limestone sand, and did not contain any bone fragment (Arredondo Leiva, Goudiaby, and González 2015, p. 255). Even sieving the fill did not yield any osseous material. Was the tomb ever occupied? Was it built for a deceased who never came, a person who died far from home? There are other cases of empty pits or cists in Naachtun, as in Group B Patio 22, where a cist in Structure 50-136, also filled with sascab, proved to be empty (Barrientos Juárez 2016, p. 172 and fig. 29). This context seems to have been disturbed during pre-Hispanic times. Another example, presenting a likely parche (repaired floor), is documented from Group A great pyramid XX (Cotom 2016, p. 521). In this second case, however, the pit did not contain any arrangement: neither cist, capstones nor slabs. By contrast, Burial 40 was apparently ready to house a body and may 
even have contained one. This last possibility does not go without taphonomical challenges: if the body was removed long after decomposition, one could expect the labile articulations and smallest parts, particularly the hands, feet and some teeth, to remain in the cist (Duday 2009, p. 89). Unless the tomb was extensively cleaned, we must suppose that the body was displaced shortly after death and/or that it was in a shroud preventing even the smallest bones from falling, or that Burial 40 was never occupied.

\section{Burial 41: the cortinero (Maax 2)}

Burial 41 was located beneath Structure 5N-6's bench, sealed by the same plaster floor as were Burials 40 and 45 (Goudiaby 2018, vol. 1, p. 280-287). It was a hybrid funerary structure (Figure 8a, next page): a pit dug in the backfill and covered with stone slabs. The individual was an adult male, extended on his back, his forearms crossed on his chest, his face covered with a broad tripod dish with sawed-off feet. A layer of ashes containing no fewer than 20 different wood taxa (Dussol 2016, p. 428) covered the skeleton. These were doubtlessly a component of the mortuary sequence and intervened at some point in the ritual event. A most intriguing feature is the presence of a cortinero (or cordholder) in the bench just above the head of the subject, an element that generally served to hold curtains. This is clearly not a "logical" position for such an implement, which should be flanking a door with a counterpart on the opposite side. Therefore, we must assume that it was linked to the presence of the burial.

\section{Burial 45: the Tikal Dancer (Maax 2)}

This burial is an exceptional case in Naachtun's mortuary record. Located approximately $1 \mathrm{~m}$ to the east of Burial 41, it was covered by the same bench and floor as were Burials 40 and 41. Burial 45, however, is very different. The subject, a male adult, was laid on his back in a tightly flexed position (Figure 8b), uncommon at Naachtun but widespread at neighboring Uaxactun. A simple cylinder was positioned at his feet, and over his skull was a perforated "Tikal Dancer"-style tripod plate.

It depicts a dancing figure, often interpreted as the Maize God. Besides their already-mentioned links with death and rebirth, the "Tikal Dancer" plates are extremely useful to us: they were produced in workshops around Tikal and Uaxactun between 675 and 800 CE (Culbert 1993, p. 4; Looper 2009, p. 122), an excellent contextual and chronological framework. Combining this range and the radiocarbon date, we may suppose that Burial 45 was installed between 675 and $740 \mathrm{CE}$. Among the more than 80 "Tikal Dancer" plates known in the entire Maya area, only seven come from controlled archaeological contexts. Most came from burial contexts, and it has been hypothesized that Dancer plates could be a funerary-dedicated production (ibid., p. 123; Mayer 2010, 


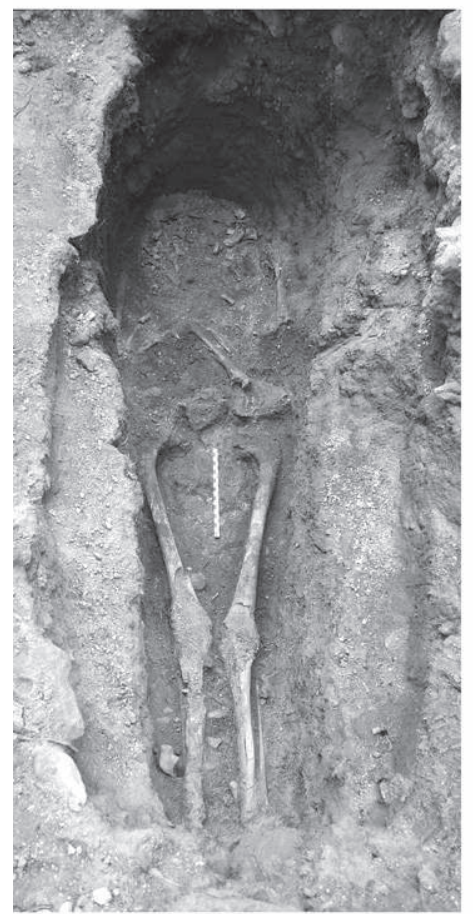

a. Burial 41

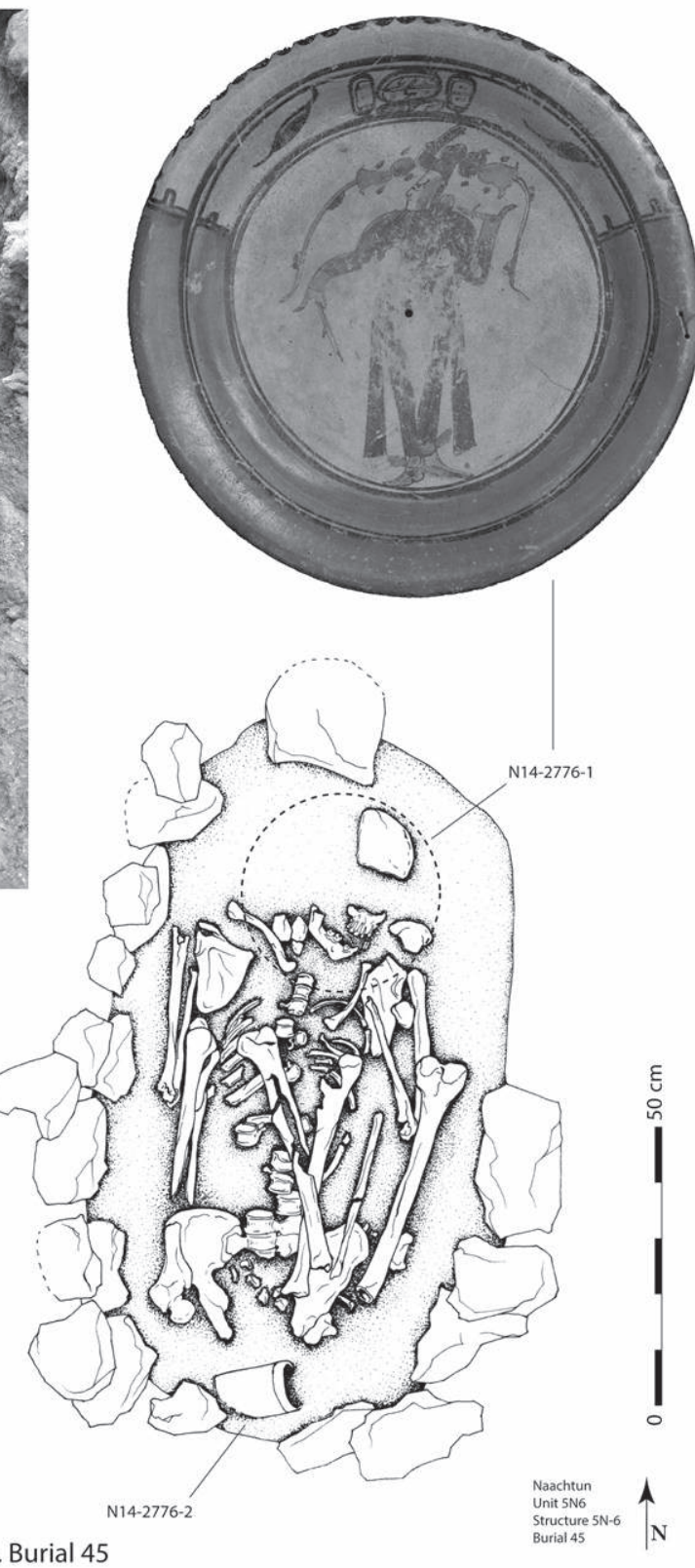

Fig. 8 - a. Burial 41 after the first excavation step; b. Drawing of Burial 45 and photograph of the Tikal Dancer plate (drawing and photograph of Burial $41 \mathrm{H}$. Goudiaby, photograph of the plate E. Mencos). 
p. 100-101). Burial 45 seems to confirm this trend, but the presence of a repair on the lip could indicate that the plate had another use before joining the grave. It could also have been broken accidentally shortly before or during the funeral. The discussion remains open.

\section{Structure 6N-1}

Finally, it was also during Maax 2 that the isolated Structure $6 \mathrm{~N}-1$ was built, $40 \mathrm{~m}$ west of the main compound. In similar fashion to Group 5N6, the building area was leveled beforehand with a thick layer of black clay. Its approximate measurements are $15 \mathrm{~m}$ north-south and 3-4 m east-west, if we are to trust the mound's dimensions (Goudiaby 2017). The interior space was subdivided into two 1-m-wide parallel rooms, a narrowness that usually defines non-residential buildings. The exact length of these rooms is unknown, for they extend beyond the trench's limits; however, it should be noted that in the visible architecture, no bench could be identified. Whether or not Structure $6 \mathrm{~N}-1$ was a residence and functioned in tandem with Group 5N6 or was completely independent is a matter of debate. However, its construction during Maax 2, its unusual arrangement, and even the nature of its founding burial (Burial 93, discussed below) render the first possibility attractive. Whatever the case, it reinforces our opinion that Maax 1-2 was a phase of intense activity in this sector. The number of burials related to this phase alone confirms this phenomenon.

\section{Burial 93: the secondary burial}

Burial 93 was placed under Structure 6N-1 after the terrain was prepared and leveled, but before construction began. From above, the grave looked like a short, 1-m-long and 50-cm-wide cist covered with three massive slabs. However, the interior dimensions did not match the exterior ones: a $40 \times 20 \mathrm{~cm}$ "chest" contained a perforated plate covering the fragments of an adult's cranium to the north, badly damaged fragments of a single long bone at the center, and to the east a bowl broken by the combined pressure of the stones and sediment. The few teeth recovered presented jadeite inlays (Goudiaby 2018, vol. 1, p. 323-328).

Burial 93 is one of those rare occurrences where not only can a deposit be identified as secondary (in the sense that decomposition took place elsewhere, see Leclerc 1990, p. 16), but also a funerary intention is demonstrable (Goudiaby in press). The cist was built significantly larger than necessary, and the different elements were arranged so that the "idea" of a fresh inhumation was maintained: a perforated plate to cover the face, as would be the case at Naachtun; the cranium to the north; a formally built cist to protect the dead. Its stratigraphic position demonstrates Burial 93's strict anteriority to Structure 6N-1, and the absence of substructures binds the two tightly. It is as if the nature of this building required the presence of a dead forebear, and a prestigious one if we are to judge by the 
jadeite inlays. We may suppose that, without any recent death, the residents had to re-enter another burial and recover the most symbolically powerful bones to "recreate" a funeral at the new locus. Of course, such an observation raises a number of questions, and these will be addressed in the final discussion.

Maax 3 (AD 750-830)

After its growth during Maax 1-2, Group 5N6's development seems to slow down during Maax 3, a phenomenon marked by a significant decrease of the overall building quality. How this correlates with fluctuations in the number of inhabitants is a matter of speculation, but there is no doubt that Maax 3 is a phase of transition at a city-wide scale. The dynamics we observe in Group 5N6 are not surprising in such a context of clear rupture in Naachtun evolution (Nondédéo et al. in press; Dussol 2017).

Structure 5N-9-bis

On the southern side of the patio, Structure 5N-9-bis was erected; this 11.50-m-long lozenge structure was built after the eastern part of $5 \mathrm{~N}-9$ was heavily modified to open a door in its lateral wall, creating a chicane entrance that isolated the courtyard from the outside. By closing the southeastern corner of the patio, 5N-9-bis added privacy to the residential space. The new building architecture is immensely inferior compared with the others: made out of rough stone blocks partly hidden behind salvage slabs from $5 \mathrm{~N}-9$ and other unidentified sources, it reflects a degree of deterioration from Group 5N6's previous standards (Goudiaby, Lacomme, and Schwendener 2016, p. 203).

\section{Structure 5N-7}

The only major evolution during Maax 3 in terms of quality, one that does not follow the downward trend of the phase, occurs on the east side of Structure 5N-6. There, Structure 5N-7, an irregular, trapezoidal-shaped single-roomed and vaulted construction, was built on what was previously a small lateral platform. Surprisingly, an imposing bench obstructed part of the doorway on the western side. Although the architecture of this building is far from perfect, the bench itself demonstrates a certain degree of care, making it one of the best built of the patio group. A meter east of the bench, the mysterious Burial 61, installed just before the construction, perforated the former floor and was sealed by the new one (Goudiaby, Lacomme, and Schwendener 2016; Goudiaby 2017; Goudiaby 2018, vol. 1, p. 230-231).

Burial 61: the double burial (Maax 3)

Burial 61 (Figure 9) is one of the most intriguing funerary contexts we encountered in Group 5N6. It was a multiple deposit with two individuals, a unique case 
The funerary and architectural history of an ancient Maya residential group
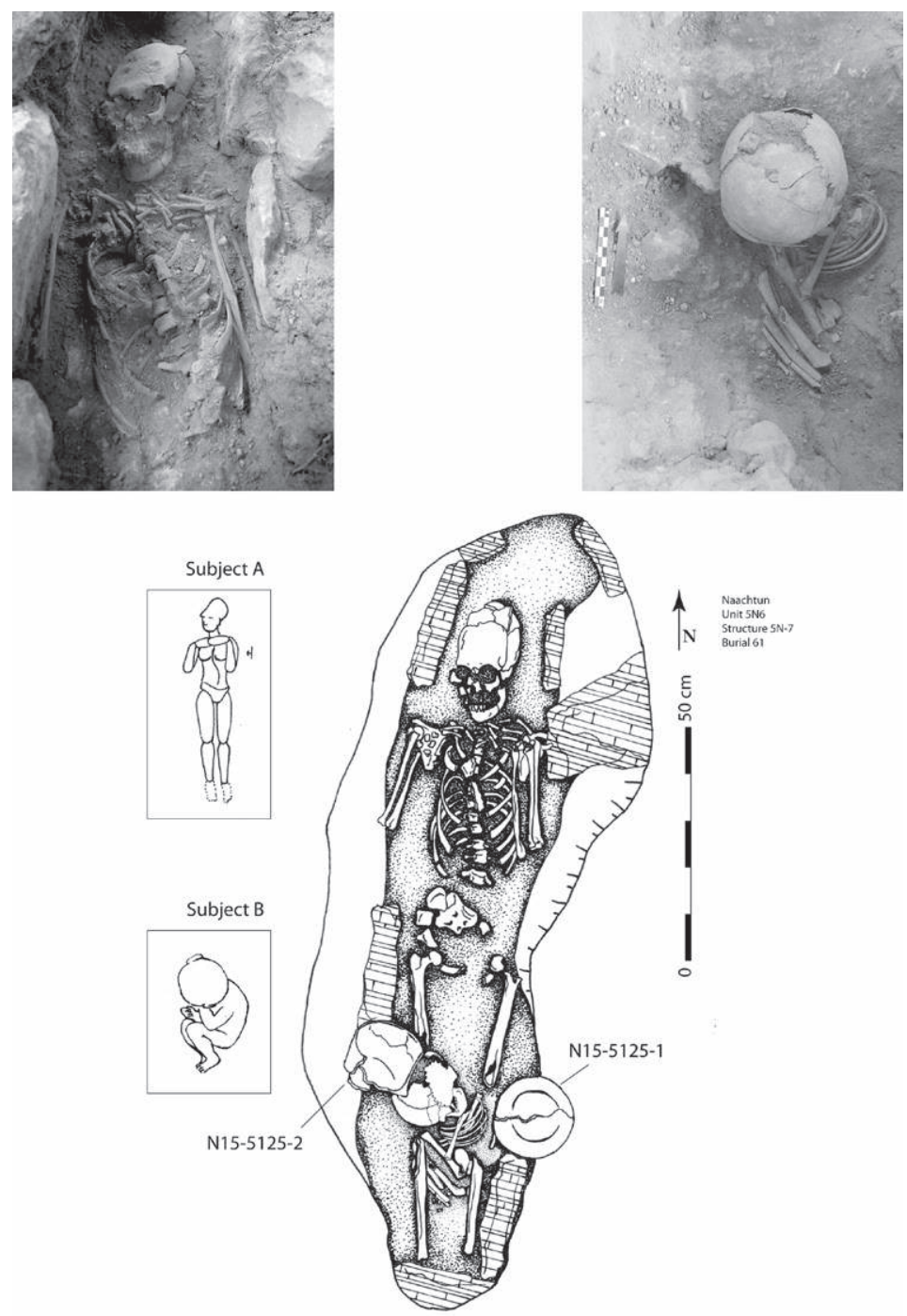

Fig. 9 - Drawing and detail photographs of BU 61, showing the original position of subjects A and B and the ceramic wares that accompanied them.

Such an elaborate disposition is unique in Naachtun's residential spaces, and rather exceptional at other sites (drawing and photographs H. Goudiaby).

in Naachtun's residential record (it could be less uncommon in royal contexts if we are to judge by the Minimum Number of Individuals (MNI), see Barrientos Juárez 2018, p. 148). The grave was not a true cist, but an oval pit partly delimited by a series of vertical slabs and covered with rough stones directly 
disposed on the first individual's body. Luckily, it did not alter the exceptional preservation of the bones, which may be attributed to the ashy sediment with which the pit was filled (Goudiaby, Lacomme, and Schwendener 2016, p. 208; Goudiaby 2017; Goudiaby 2018, vol. 1, p. 307-315).

Subject A was a middle adult, probably female, as indicated by the overall skeletal gracility, the sciatic notch (Brůžek 2002) and as suggested by Wrobel's functions (Wrobel, Danforth, and Armstrong 2002). She was extended northsouth, according to the local tradition; her hands rested on the upper thoracic area just below her chin. The most striking feature was the extreme tabular oblique deformation her skull exhibited (Tiesler 1999, p. 207). A pair of ceramic vessels (a composite bowl and a small tripod plate) was positioned west and east of her knees, respectively. Subject B appeared $5 \mathrm{~cm}$ deeper, between the knees of subject A. He rested tightly flexed on his right side, directly on a turtle plastron

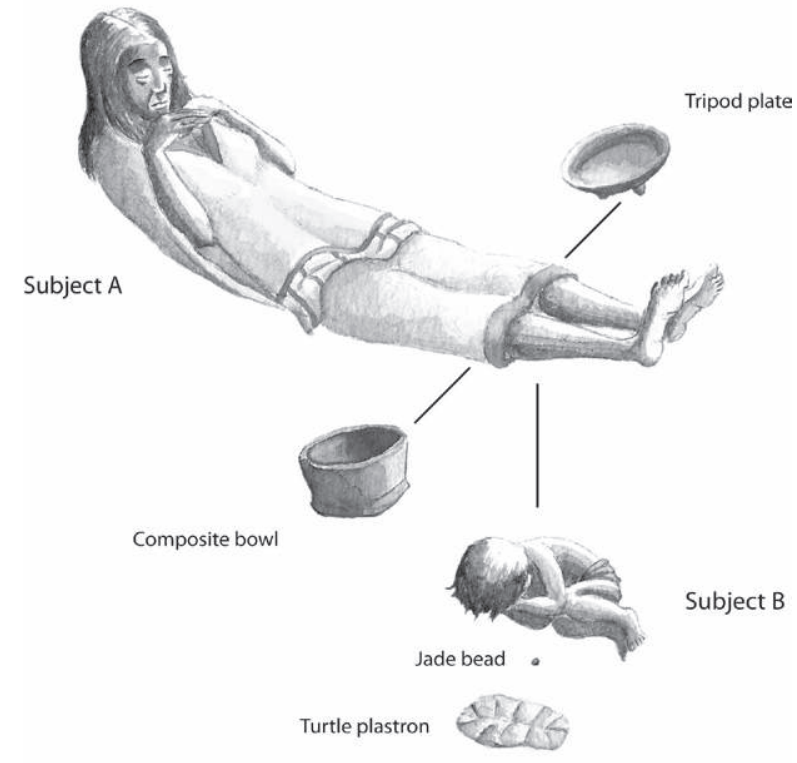

Fig. 10 - Reconstitution of BU 61 showing the vertical and horizontal structuration of its components (drawing H. Goudiaby). and a jade bead (Figure 10). ${ }^{9}$ The combination of measurements, dental development and epiphyseal closure indicates that subject B was about three years old (Liversridge and Molleson 2004; Moorrees, Fanning, and Hunt Jr. 1963; Scheuer, Musgrave, and Evans 1980). He presented a very interesting anatomical anomaly: the dental fusion of the inferior right incisors, characterized by a soldering of the dentine (Marrades 2013). This malformation is benign, but an extremely advanced tooth decay also affected the superior left medial incisor and could be the cause of the death following infection.

In terms of taphonomy, subject A was anatomically coherent. The labile articulations of the hands and feet were perfectly preserved, and the volumes of the ribcage that contained the sternum and manubrium in anatomical order and distance

9. This unusual disposition certainly warrants a more in-depth analysis, as it is reminiscent of a cosmogram. This topic will be addressed in the proceedings of the 3rd International Colloquium of Bioarchaeology, held in Merida in October 2018. 
demonstrate that decomposition took place in a filled space (Duday 2009, p. 52-57). Subject B, on the other hand, presented numerous taphonomic anomalies of the vertebral column, including thoracic and lumbar bodies near and inside the cranium (Goudiaby 2017; Goudiaby 2018, vol. 1, p. 312-313). These displacements represent movements of more than $25 \mathrm{~cm}$ from the original anatomic position, which is considerable for such a young subject. The only explanation we may offer is that subject B could in fact be a secondary deposit with maintained connections. It is a plausible explanation if we envision a mortuary bundle maintained by ropes that prevent excessive movements of the extremities but allow the smallest parts of a child's skeleton to move freely (for an illustration of such a bundle, see, for instance, Huchet et al. 2013 or Mansilla Lory and Pijoan Aguadé 2000). The subject would have been deposited temporarily elsewhere, and then buried with subject A. The abnormal observed movements would result from this translation. Of course, we cannot exclude the possibility of a simultaneous death of both individuals, but the probability is low even considering the age at death of each subject (Chambon and Leclerc 2007, p. 292). As for the hypothesis of an intentional killing, there were no evidence of violent death on the bones to support it, even if poisoning or strangulation remain a possibility, however remote.

\section{Structure $5 \mathrm{~N}-8$-bis and evolution of $5 \mathrm{~N}-5$ and $5 \mathrm{~N}-6$}

It was also during Maax 3 that the annex $5 \mathrm{~N}-8$-bis, a perishable structure on a low stuccoed platform, was abutted to the southern wall of Structure $5 \mathrm{~N}-8$. It may have been used as a storage room, as the number of utilitarian pots broken on its floor suggests (Goudiaby, Lacomme, and Schwendener 2016). In the other buildings, minor transformations occurred with the installation of the last burials, 43 and 51. In Structure 5N-5, Burial 51 was located in the sealed passageway between the central and the northern room; immediately after, the bench was extended over the grave, without repairing the floor. As for Burial 43, it occupies the first lateral room of Structure 5N-6. Said room was sealed shortly after the inhumation; a radiocarbon date obtained in the tomb indicates AD 666-863 (Lyon-12476), which corresponds to the end of the phase and probably closes the burial sequence.

\section{Burial 51: the sealed door (Maax 3)}

Attributed to Maax 3, Burial 51 (Figure 11, next page) is a perfect example of the impact burials may have had on the built environment. We already mentioned the narrow passageway that connected Structure 5N-5's central room to the northern one. At some point during the occupation, Burial 51 was installed in this very passage, which was immediately walled. The central room's northern bench was extended to the east over the burial and a cortinero was encased in 


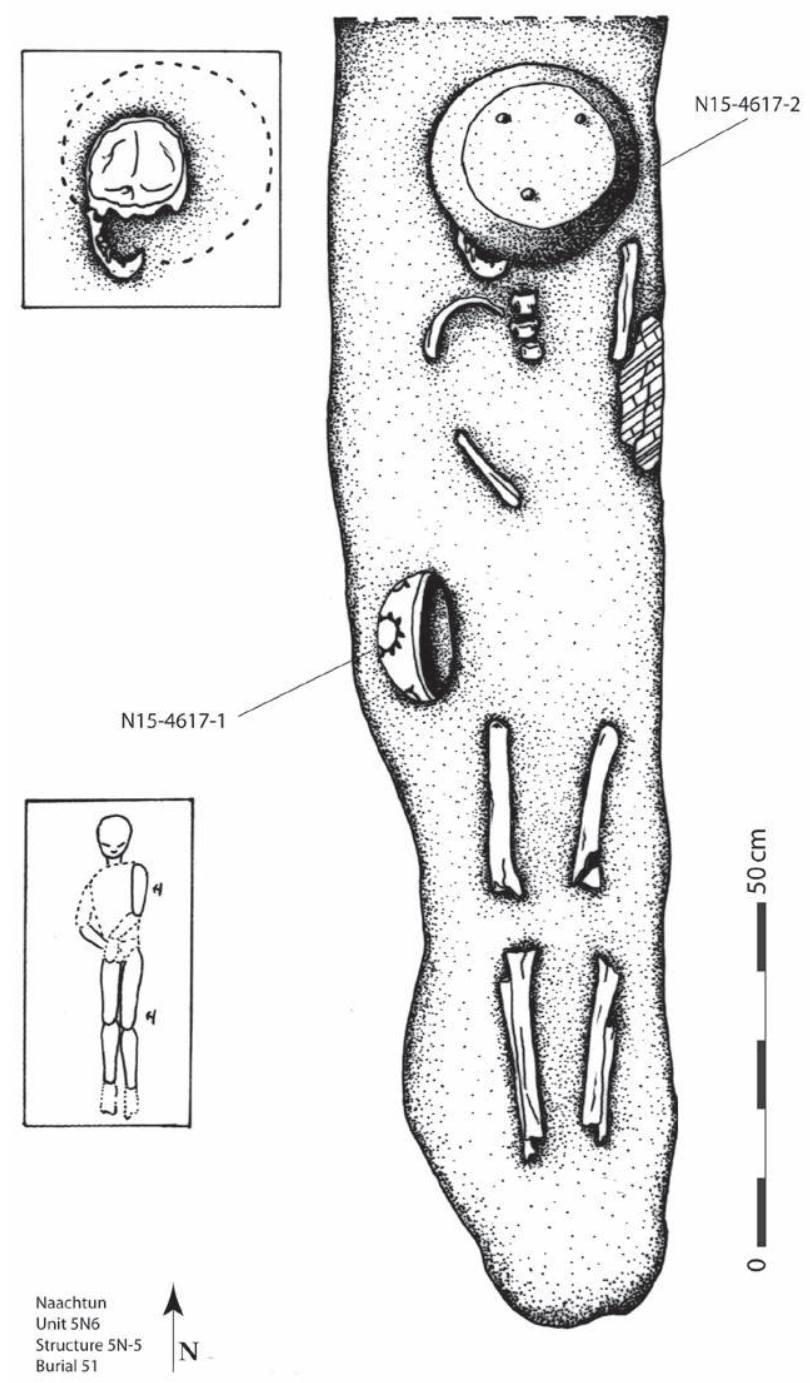

Fig. 11 - Drawing of Burial 51. The northern part (dotted line) corresponds to a wall that was built above the burial immediately after its installation (drawing H. Goudiaby).

its front. Similar to Burial 41, this one had no counterpart either (Goudiaby, Lacomme, and Schwendener 2016, p. 205). All these actions took place in a single construction effort, as indicated by the absence of a parche over the grave except at the southern end of the pit: the grave being longer than the bench, the inhabitants only repaired the exceeding centimeters visible on the 
room floor. The skeleton of the subject, laid on its back with its skull to the north, was badly damaged. Luckily, the long bones were sufficiently preserved to observe their gracility and allow the use of Wrobel's discriminant functions to indicate female characteristics. A polychrome bowl accompanied the subject, and a non-perforated tripod plate covered her face.

Burial 51 is quite standard according to Naachtun's dominant norms, but for once the impact of its installation is particularly visible: after the inhumation of this individual, it was not possible to pass from one room to the next without going out of the building. The consequences of such an event on the residents' everyday life is obvious, if minor. None could ignore the fact that the installation of this burial modified the circulation axes.

Burial 43: the final burial (Maax 3)

The last burial in the compound was set in the first western room of Structure 5N-6. There, the floor was entirely burnt, and a slight oval subsidence at the center signaled the presence of a mortuary context (Arredondo Leiva, Goudiaby, and González 2015, p. 257). It turned out to be a repaired intrusion through the plaster floor, indicating that Burial 43 (Figure 12) was installed during the occupation. Once again, the crude arrangement of the 70-cm-deep pit resulted in a high degree of damage to the bones, as a series of stones had been aligned directly on the body. The remains were sufficient to determine that the

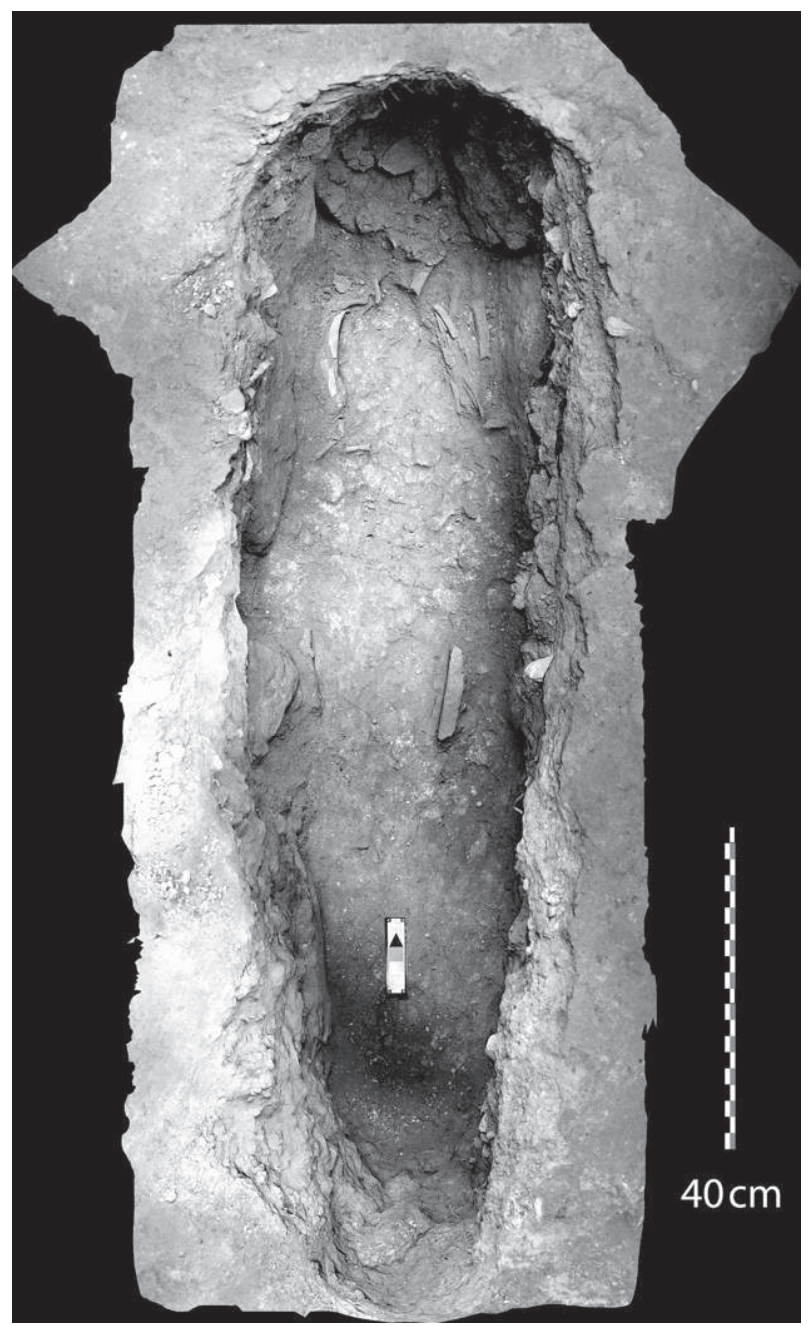

Fig. 12 - Orthophotography of Burial 43, one of the most damaged subjects of the entire unit (drawing and photographs H. Goudiaby). 
adult was laid on their back, arms folded on their chest, head to the north. No ceramic covered the skull, but a jadeite hatchet was deposited near the left thigh. The bones were remarkably slender, and the few measurements that could be obtained from the remaining long bones were extremely feminine (Wrobel, Danforth, and Armstrong 2002).

The interpretative challenges regarding Burial 43 are more context-related than taphonomic or biological. The door that communicated the main room with the lateral one, where the tomb was located, had been walled up. This closure amounts to $60 \%$ of the building being abandoned. We cannot be sure that the sealing was a consequence of the burial, nor when it occurred precisely; a radiocarbon date obtained in the burial places it in the AD 666-863 range (Lyon-12476). If we are to judge by the ceramics, this range can be narrowed to AD 740-863, which corresponds to the end of the unit's occupation. The inhabitants may have been very few at this time and thus could afford such an important loss of space. If we observe the closings in Group 5N6, they all occur during Maax 3, at a time when the unit was in decline and the departure imminent. If the room was walled up late after the burial, several possibilities can be envisioned to explain it. None, however, is without flaws. Why would this particular burial deserve such isolation? Did it present any kind of danger? Was it, on the contrary, a measure to protect against potential disturbances? Is it even related to the presence of the tomb? There is no answering these questions, but Burial 43 set a definitive end to Group 5N6's sequence of inhumations.

The abandonment

No Terminal Classic material was recovered during the excavation, which leads us to suppose that the abandonment of Group 5N6 certainly took place during Maax 3. It was probably not a precipitate, disordered departure, but a very carefully planned one that left several material traces - a scenario regularly observed not only in Naachtun's residences and public spaces (Sion 2016), but more generally in the Maya area (see, for instance, the case of Minanha; Zehrt 2012, Lamoureux St-Hilaire 2015). Structures 5N-8 and 5N-9-bis' western doorways were carefully walled over to prevent access to the rooms after two abandonment deposits were made on their main axis (Arredondo Leiva, Goudiaby, and González 2015, p. 262). In 5N-9, Burial 54 was re-entered and the left tibia and femur of the individual withdrawn. A femoral diaphysis was found in 2014 near 5N-9's central doorjamb (ibid.) and could well pertain to this same individual. The symbolical barring of doors with human long bones is not exceptional in Naachtun's records: another, better-preserved example comes from Group B, Structure 6O-15 (Sion 2014). After this careful closure event, the last inhabitants abandoned the unit. 


\section{Discussion}

Group 5N6's history encompasses at least three hundred years. Observing its evolution from a single-structure household to a fully developed residential compound is particularly interesting, for it highlights the role of dead forebears in this growth. Indeed, the only building that was not erected on a founding burial is Structure 5N-5 (doubts persist for Structure 5N-9-bis, as its floors could not be tested). The presence of a dead forebear clearly appeared as a necessity to Group 5N6's residents. This aspect is rather intriguing, less from an ideological perspective - which has been quite developed in previous works (e.g. Barnhart 2002; Geller 2014; McAnany 1998, 2013 [1995]) - than from a practical one. Death is hardly a foreseeable phenomenon, except when it results from a long illness or old age, in which cases it is more easily anticipated. How to explain, then, the systematic presence of burials prior to the construction? Haviland's proposal of a rotating system, resulting in the elder of each generation moving to live in the founder's house at his predecessor's death and being interred in it (Haviland 1988), does not seem to function in Group 5N6, considering that a majority of the discovered burials clearly preceded the main building effort. Taking into account the age of the individuals is of little help. Indeed, all of them are adults (except subject 61B whose status is unclear), the youngest one (Burial 54, see Goudiaby 2018, vol. 1, p. 302-307) being approximately 20 years old at the time of their death (Moorrees, Fanning, and Hunt Jr. 1963; sex undetermined). None of the individuals, possibly excluding Burial 53, pertains to a particularly vulnerable age class (Buchet and Séguy 2011; Ledermann 1969). A mechanism permitting the construction of new buildings only when prominent family members died certainly seems unreasonable, whatever its ideological foundations. On the other hand, a funerary system that would require the erection of a new building at every important death would not be much easier to deal with, especially in the occasional case of multiple deaths over a too short period. There is necessarily a degree of flexibility in these practices; otherwise such a system would be, mechanically, a race against decomposition. ${ }^{10}$

10. Even more so considering the fact that "true" secondary burials are quite difficult to identify in ancient Maya residential contexts. A word of precision may be in order here. The French school distinguishes between secondary burial and secondary deposit, which stems from intense debates around the mere notion of burial (see Leclerc 1990; Duday 2009, p. 76-78 for a synthesis). It may create misunderstandings as concepts do not necessarily translate well to other languages. As stated by Duday (2009, p. 89-91), the notion of preplanning is key, as well as that of positive intention directed towards the dead (Leclerc 1990, p. 16-17). A secondary burial (sépulture in French) is the result of protracted funerals as defined by Hertz (1907): the body is temporarily stored and left to decompose until the time comes to bury it definitively somewhere else, to ensure the dead's well-being. By extension, the re-deposition of skeletal remains accompanied by an identifiable funerary ritual also falls into this category, even if the two-step deposition was not pre-planned. A secondary deposit 
These remarks lead us to emphasize the contextual differences between the graves. Indeed, Group 5N6's burials can be regrouped according to the importance of the architectural modifications that surround them. It is obvious that Burials 41, 45, 53, 54 and 61 preceded significant building efforts, with the erection of new structures; the reopening of Burial 54 is also an important gesture to keep in mind. Burials 51 and 89 had a much more limited impact, affecting only one room at a time. Burials 43 and 93 were not associated with major changes except the possible sealing of their rooms, which cannot be strictly related to the presence of the burials, at least from a stratigraphic point of view. Burials 28 and 32 were located in the courtyard and not associated with any kind of building evolution.

In this list, Burial 93 was left aside because of its unusual character, which warrants an extended discussion. Indeed, it appears to be the last step of a specific mortuary sequence that involves re-entry and re-inhumation. Re-entry, which we define simply as the intentional reopening of a funerary sealed context (Goudiaby 2018, vol. 2, p. 136), is attested to in the iconography but also in the epigraphy, as on Tikal's altar 5 or Yaxchilan's lintel 25 (Fitzsimmons 2009, p. 166; Stuart 1998; Eberl 2005). Several examples also exist in the archaeological record in the elite sphere as well as from more modest contexts; Scherer recounts cases of missing skulls from Bonampak and Busilha, and skeletons without tibias from El Kinel (Scherer 2015, p. 98-99). Kohunlich's Burial 2 was interpreted as a case of ancient looting (Nalda et al. 1997), but the position of the coxal bones indicates more likely the recuperation of a femur, the hip bone dragged alongside it over the left forearm. An exhaustive list of such cases is not necessary here; however, it is interesting to note that such re-entry events seem to occur at various levels of ancient Maya society, even if a majority of documented occurrences come from the elites (Smith 1950, p. 102; Welsh 1988, p. 81-89; Tiesler and Campaña Valenzuela 2004). At Naachtun, re-entry is widespread in royal burials from the Early Classic period as well as in late, post-royalty nobility residential contexts (Barrientos Juárez et al. 2015; Lacomme 2017).

The real question is to determine the purpose of such re-entries, rather than to identify them correctly. Fire-related mortuary rituals are often mentioned in high-ranking contexts (Stuart 1998, p. 339; Weiss-Krejci 2003, p. 79;

(dépôt in French) is the result of a displacement of dry skeletal remains, but it is not necessarily intentional or funerary. A long bone taken from a grave to be re-used in abandonment or dedicatory rituals, a fairly common case at Naachtun, is a secondary deposit but not a secondary burial. The introduction of such a nuance is important when reconstructing and interpreting the intentions of the living, as it avoids transforming every isolated bone into a funerary context. In such cases where intentionality is not demonstrable, the most neutral option is always adopted by default. This observation does not encompass the remains disturbed during re-entries, which is a particular type of intervention on primary burials (Goudiaby 2018b, p. 138-141). 
Fitzsimmons 2006; see also Tiesler 2018, p. 218-220). In systems that involve collective burials, making space for another deceased is often simply the reason (at Caracol, for instance, see Chase and Chase 2015, or at Cuello and K'axob for earlier periods, see Oblado 2011). The recuperation of relics is another possibility that existed at least among the elites (Fitzsimmons 2009, p. 183; Tiesler and Campaña Valenzuela 2004). The removal of bones for purposes of abandonment rituals is a third: doors could be symbolically barred with long bones, a rather common ritual at Naachtun (Sion, Arnauld, and Antillon 2012). For instance, in Group B Patio 28, it has been demonstrated that all the dispersed bones found in all room entrances and on the stairs came from Burial 34 reentered and nearly entirely removed at the moment of abandonment (Sion 2016). A similar practice, on a smaller scale, may have occurred in Group 5N6 with the bones of subject 54's left limbs'.

Indirectly, Burial 93, resulting from a re-entry, shows that this practice could also be motivated by the necessity to found new structures. This represents the other extremity of the chain-we know why the bones were taken, but not from where. It is also a unique case in Naachtun's record, both because it is the earliest to date, and because so much care was taken to craft it. Some would certainly consider it a cache rather than a burial; it has been observed that the distinction is sometimes unclear both in the field and symbolically (Becker 1992, 1993). We consider it a secondary burial rather than a cache because of its layout. It was carefully staged; the disposition of the wares matching exactly Burial 51's (dating to the same period), the perforated plate over the skull, the long bone, the absence of any other element usually associated with caches are all in favor of this interpretation. We suppose that this particular context is testimony to the builders' need to link a forebear to the building, without having any recently dead relative to bury. Such a need could explain a number of re-entries and interventions in ancient Maya burials (Barrientos Juárez et al. 2015; Goudiaby 2018, vol. 2, p. 136-138; Nalda et al. 1997; Sion, Arnauld, and Antillon 2012; Welsh 1988, p. 81-89). It also questions the notion of "problematical deposit" that is sometimes employed to describe ambiguous contexts (Becker 1993, p. 47) and highlights its interpretative difficulty.

In the absence of other markers, we suppose that all the aforementioned differences between burials are linked to the status of the deceased in the social group. There is no reason to think that a person like subject 54 could not have been buried in Structure $5 \mathrm{~N}-8$, which already existed at the time of his or her death. The same could be stated for subject $61 \mathrm{~A}$, and the erection of Structure $5 \mathrm{~N}-6$ to cover burials 40,41 and 45 certainly represented an important investment. The recuperation and re-deposition of subject 93's bones in a new grave is testimony to the importance of this individual. In contrast to these examples, there is no physical, immediately apparent reason not to build a structure for subjects 51 or 89 . Still, the residents decided not to do so. Therefore, we believe 
that there existed a set of rules according to which every member of the family group was buried, depending on his or her status. The circumstances of the death, during a building effort, for example, could also play a part in the system: the deceased could be opportunistically integrated to the new structure. In the majority of cases, however, at least in Group 5N6 and certainly beyond, the impact a death had on the residential built environment was probably correlated to the importance of the deceased in the eyes of the living.

On the basis of all these observations, we could tentatively propose the following points in relation to the funerary sequence in Group 5N6:

1. It is fairly plausible that the growth of the first social group (a first family?) justified the building of Structure $5 \mathrm{~N}-8$, Burial 53 possibly being the founder and thus most important member. We know that Group 5N6 started fairly small, so the construction beginning just after this individual's death is not an unrealistic hypothesis: the family members were probably not so numerous at this time, implying that the construction could wait a little.

2. The timespan between the construction of Structures $5 \mathrm{~N}-5$ and $5 \mathrm{~N}-9$, on the other hand, is rather blurry; nonetheless, the construction of two imposing structures seems rather implausible without a population influx to justify it. We do not know exactly what happened at this time, but there seems to be a surge in occupation with the sudden appearance of these two buildings. The residential mobility of ancient Maya may account for this, but although firmly attested to, the range of such patterns is still a matter of debate (Novotny 2015, p. 360-367). Ongoing isotopic analyses should shed some light on that matter. Subject 54's death alone does not seem enough to trigger such a construction effort, even if we consider the eventuality that Structure $5 \mathrm{~N}-9$ could have been originally designed to be a reception building. Therefore, its presence may well be circumstantial. It remains a prominent subject nonetheless, as the placement of this subject's grave (linked to a later bench) and its subsequent reopening testify.

3. Burials 40, 41 and 45's simultaneity could be an impression given by the stratigraphy, rather than an objective fact. Indeed, radiocarbon dates clearly establish that Structure 5N-6-Sub's locus was unoccupied long enough for this small space to become a funerary space of sorts. These burials could precede, although not by much, the construction of Structure 5N-6. This reduces greatly the need for anticipation, as well as the interpretative stretch that is the simultaneous death of two individuals. ${ }^{11}$ The refill

11. Simultaneity is quite a difficult notion to establish both theoretically and archaeologically (Boulestin 2008). It has been determined by Chambon and Leclerc that two deaths separated by an interval of approximately one week remain "simultaneous" (Chambon and Leclerc 2007, p. 292). But the same authors recognize that the admissible delay for simultaneous funerals is a sensitive parameter, even if more than 10 days is unlikely (ibid., p. 299). 
could also marginally predate the floor construction; whatever the option, the presence of these three burials clearly bestowed importance upon the building above them.

4. In the case of Burial 51, anticipation was not needed, as the burial was installed within an already-existing building. There was enough space on the southeastern side of the patio for a new construction, but the inhabitants decided to dig through Structure 5N-5's floor instead, which clearly demonstrates that they did not need a new structure at this time - or that the person interred was not important enough to justify it. It could also indicate that the person was a resident of Structure $5 \mathrm{~N}-5$.

5. In contrast to 51, Burial 61 is typical of a locally very important context. One can even wonder if, at this time of Group 5N6's history, a new construction was really needed or if the construction of Structure $5 \mathrm{~N}-7$ obeyed a more symbolic necessity. The investment in this construction was considerable even if $5 \mathrm{~N}-6$ shares its east lateral wall with $5 \mathrm{~N}-7$, and the layout of the burial is more meticulously planned than any other. All of this points to a certain degree of anticipation, as well as a great importance for subject A. Subject B's status is less evident.

\section{Conclusion}

The ins and outs of ancient Maya residential funerary practices go way beyond the scope of this paper. Literature on the topic is vast and the present study does not pretend to encompass it all. However, the gathered data are sufficient to discuss some particular points at least on a local scale. Our results show that two central notions for the understanding of ancient Maya funerary practices are rhythm and anticipation (or lack thereof). The term "cycle" has sometimes been used to describe this dynamic of burials, modifications and re-entries (Chase and Chase 2004). The term itself carries a circular notion: a chain of events that comes back to its origin and repeats itself, always in the same order. We are not sure it is appropriate and corresponds to our data. Whatever the case, the question is: how much time passed between two links of this chain? Are residential spaces so tightly associated with their inhabitants that their evolution is indexed on the duration of human life, with all its randomness? This idea, implicit in Haviland's work on Tikal's Group 2G-1 (Haviland 1988), certainly comes to mind when an exhaustive enough excavation allows the reconstruction of a near-full funerary sequence. Group 5N6 gives the impression of a compelling need to associate the family's important dead to buildings whenever possible,

In the Maya system, it may be longer. Indeed, the overarching need to associate important family members and buildings may have resulted in an adaptation of mortuary strategies. 
while resorting to other options like re-entry and secondary burial when the need was too pressing and nobody had recently died.

This last statement goes against any idea of calendar-fixed intervals of time. While such a possibility is viable for commemorative acts, its application to mortuary practices would involve at least a system for the storage and retrieval of the bodies. Nothing we are aware of in the archaeological record points towards such a possibility. Ancient Maya residential funerary practices were more probably a mixture of anticipation, last wills and improvisation in the face of sudden deaths. This is probably truer for commoners and intermediate elites than for the royal court, which seems to be held by another layer of obligations (Fitzsimmons 2009, p. 179). Comparisons with other funerary sequences, from sites with different practices, would certainly offer more insight into a mechanism that remains poorly understood to this day. *

* Manuscrit reçu en juin 2019, accepté pour publication en mars 2020.

Acknowledgements - Group 5N6's excavation was part of the first author's Ph.D. program, and we wish to thank all the people who helped him during this task, especially the workers from Uaxactun. We thank the members of the Naachtun Project team, with special gratitude to Isaac Barrientos Juárez for his help with osteology and Alejandro Patiño-Contreras, Julien Sion and Divina Perla Barrera for the dating of each context. Special thanks are owed to Dominique Michelet for the frequent visits and fruitful discussions we had during the excavation, and to Grégory Pereira for his direction during those four years. We also thank Eric Taladoire for his corrections and his helpful suggestions, and Justin Dyer for his in-depth revision of the text. The Naachtun Project (2010-2018) was supported by the ministère de 1'Europe et des Affaires étrangères (French Ministry for Europe and Foreign Affairs), the CNRS, the Perenco Company, the Pacunam Foundation, the Foundation Cino del Duca, the LabEx DynamiTe and the Archéologie des Amériques laboratory (ArchAm, UMR 8096). Centro Francés de Estudios Mexicanos y Centroamericanos (CEMCA) offered institutional support. Financial support for this study was provided by the University Paris 1 - Panthéon-Sorbonne and the Fondation des Treilles. The Maison archéologie et ethnologie, René-Ginouvès (MAE) financed the radiocarbon dating of Burials 53 and 61 as part of the project MoSt Maya, in collaboration with the Archéologies et Sciences de l'Antiquité laboratory (ArScAn, UMR 7041). All the investigations were carried out with the kind permission of the Guatemalan Institute of Anthropology and History (IDAEH).

\section{References cited}

Adams Richard E. W.

1999 Río Azul. An Ancient Maya City, University of Oklahoma Press, Norman. ANDrieu Chloé

2016 "Operación IV.2. Analisis de la litica”, in Philippe Nondédéo, Julien Hiquet, Dominique Michelet, Julien Sion, and Lilian Garrido (eds.), Proyecto 
The funerary and architectural history of an ancient Maya residential group

Petén-Norte Naachtun 2015-2018. Informe de la sexta temporada de campo, IDAEH/DEMOPRE, Guatemala, p. 351-354.

ArRedondo LeIVA Ernesto

2010 Archaeological Investigation of a Walled Compound at Naachtun, Peten, Guatemala. Architecture, Politics and Warfare, Ph.D. dissertation Archaeology, La Trobe University, Bundoora, Victoria.

Arredondo Leiva Ernesto, Hemmamuthé Goudiaby, and Giovanni GonZÁlez

2015 "Operación II.5bis. En busca de la secuencia funeraria de un conjunto residencial: el Grupo 5N6 'Matapalos'", in Philippe Nondédéo, Julien Hiquet, Dominique Michelet, Julien Sion, and Lilian Garrido (eds.), Proyecto PeténNorte Naachtun 2010-2014. Informe de la quinta temporada de campo, IDAEH/DEMOPRE, Guatemala, p. 243-282.

BARNHART Edwin L.

2002 "Residential burials and ancestor worship: a reexamination of Classic Maya settlement patterns", in Vera Tiesler, Rafael Cobos, and M. Greene Robertson (eds.), La organización social entre los Mayas prehispánicos, coloniales y modernos, INAH, México, p. 141-158.

BARRIENTOS JuÁREZ Isaac

2012 “Operación IVa. Análisis realizados a los restos óseos humanos”, in Dominique Michelet, Carlos Morales-Aguilar, Julien Sion, and Philippe Nondédéo (ed.), Proyecto Petén-Norte Naachtun 2010-2014. Informe de la tercera temporada de campo 2012, IDAEH/DEMOPRE, Guatemala, p. 227-248.

2016 "Operación II.5. Los contextos funerarios y los procesos de aglomeración”, in Philippe Nondédéo, Dominique Michelet, Julien Hiquet, and Lilian Garrido (eds.), Proyecto Petén-Norte Naachtun 2015-2018. Informe de la sexta temporada de campo 2015, IDAEH/DEMOPRE, Guatemala, p. 161-184.

2018 "Operación II.5. Los contextos funerarios y los procesos de aglomeración”, in Philippe Nondédéo, Dominique Michelet, Johann Begel, and Lilian Garrido (eds.), Proyecto Petén-Norte Naachtun 2015-2018. Informe de la sexta temporada de campo 2017, IDAEH/DEMOPRE, Guatemala, p. 147-168.

Barrientos Juárez Isaac, Julien Sion, Chloé Andrieu, Daniel SAlazAr, and Julio Cotom

2015 "Evidencias de reingreso a los espacios sepulcrales en grupos habitacionales del Clásico Tardío-Terminal en Naachtun, Petén, Guatemala", in Bárbara Arroyo, Luis Alberto Méndez Salinas, and Lorena Paiz Aragón (eds.), XXVIII Simposio de Investigaciones Arqueológicas de Guatemala, 2014, Museo Nacional de Arqueología y Etnología/Ministerio de Cultura y Deportes/Instituto de Antropología e Historia/Asociación Tikal, Guatemala, p. 465-479.

BECKER Marshall J.

1992 "Burials as caches, caches as burials: a new interpretation of the meaning of ritual deposits among the Classic period Lowland Maya", in Elin C. Danien, and Robert J. Sharer (eds.), New Theories on the Ancient Maya, University of Pennsylvania Museum of Archaeology and Anthropology (Monographs, 77), Philadelphia, p. 185-196.

1993 "Earth offerings among the Classic period Lowland Maya: burial and caches as ritual deposits", in María Josefa Iglesias Ponce de León, and Francisco de Asís Ligorred Perramón (eds.), Perspectivas antropológicas en el mundo maya, Sociedad Española de Estudios Mayas, Madrid, p. 45-74. 
Boulestin Bruno

2008 "Pourquoi mourir ensemble ? À propos des tombes multiples dans le Néolithique français", Bulletins de la Société préhistorique française, 105 (1), p. 103-130.

BRŮŽEK Jaroslav

2002 "A method for visual determination of sex, using the human hip bone", American Journal of Physical Anthropology, 117 (2), p. 157-168.

BrůŽEK Jaroslav, Frédéric Santos, Bruno Dutailly, Pascal Murail, and Eugenia Cunha

2017 "Validation and reliability of the sex estimation of the human os coxae using freely available DSP2 software for bioarchaeology and forensic anthropology", American Journal of Physical Anthropology, 164 (2), p. 440-449.

Buchet Luc and Isabelle SÉGUY

2011 Manuel de paléodémographie, INED, Paris.

CASEs Ignacio and Alfonso LACADENA

2015 “Operación III.5. Estudios epigráficos temporada 2014”, in Philippe Nondédéo, Dominique Michelet, Julien Hiquet, Julien Sion, and Lilian Garrido (eds.), Proyecto Petén-Norte Naachtún 2010-2014. Informe de la quinta temporada de campo 2014, IDAEH/DEMOPRE, Guatemala, p. 371-384.

Chambon Philippe and Jean LeCLerC

2007 "Les tombes multiples dans le Néolithique français : aléa statistique ou pratique institutionnalisée ?", Bulletin de la Société préhistorique française, 104 (2), p. 289-306.

Chase Diane Z. and Arlen F. Chase

1998 "The architectural context of caches, burials, and other ritual activities for the Classic period Maya (as reflected at Caracol, Belize)", in Stephen D. Houston (ed.), Function and Meaning in Classic Maya Architecture. A Symposium at Dumbarton Oaks, 7th and 8th October 1994, Dumbarton Oaks Research Library and Collection, Washington (DC), p. 299-332.

2004 "Patrones de enterramiento y ciclos residenciales en Caracol, Belize", in Rafael Cobos (ed.), Culto funerario en la sociedad maya. Memoria de la Cuarta Mesa Redonda de Palenque, Instituto Nacional de Antropologia e Historia, México, p. 203-230.

2015 Ancient Social Integration in a Maya Neighborhood. Investigation of Adjacent Residential Complexes near Caracol's Epicenter-Caracol Archaeological Project Investigations for 2014. A Continuation of the 2012 and 2013 Research Focus, University of Central Florida, Orlando.

Coe William R.

1990 Excavations in the Great Plaza, North Terrace, and North Acropolis of Tikal, University of Pennsylvania Museum of Archaeology and Anthropology (Tikal Reports, 14), Philadelphia.

Сотом Julio

2016 “Operación V.6. Investigaciones en la Estructura XX del Grupo A de Naachtun”, in Philippe Nondédéo, Julien Hiquet, Dominique Michelet, Julien Sion, and Lilian Garrido (eds.), Proyecto Petén-Norte Naachtun 2015-2018. Informe de la sexta temporada de campo 2015, IDAEH/DEMOPRE, Guatemala, p. 519-538. 
The funerary and architectural history of an ancient Maya residential group

Cotom Julio, Weagli Veliz, and Byron HernándeZ

2012 "Operación II.2. Sondeos estratigraficos en los grupos de patios de la periferia sur", in Philippe Nondédéo, Dominique Michelet, Julien Sion, and Carlos Morales-Aguilar (eds.), Proyecto Petén-Norte Naachtun 2010-2014. Informe final de la segunda temporada de campo 2011, IDAEH/DEMOPRE, Guatemala, p. 66-79.

Culbert T. Patrick

1993 The Ceramics of Tikal. Vessels from the Burials, Caches and Problematical Deposits, University of Pennsylvania Museum of Archaeology and Anthropology (Tikal Report, 25A), Philadelphia.

Duday Henri

2009 The Archaeology of the Dead. Lectures in Archaeothanatology, Oxbow Books, London.

Duday Henri, Patrice Courtaud, Éric Crubezy, Pascal Sellier, and Anne-Marie Tillier

1990 “L'Anthropologie 'de terrain' : reconnaissance et interprétation des gestes funéraires", Bulletins et mémoires de la Société d'anthropologie de Paris, 2 (3), p. 29-49.

Dussol Lydie

2016 "Operación IV.5bis. Analisis antracologico: depositos y contextos especiales", in Philippe Nondédéo, Julien Hiquet, Dominique Michelet, Julien Sion, and Lilian Garrido (eds.), Proyecto Petén-Norte Naachtun 2015-2018. Informe de la sexta temporada de campo 2015, IDAEH/DEMOPRE, Guatemala, p. 415-431.

2017 Feux et forêts mayas. Usages et gestion des combustibles ligneux dans les Basses Terres centrales mayas à la période Classique : approche anthracologique. Le cas du site de Naachtun, Petén, Guatemala, Ph.D. dissertation, Archaeobotany, université Paris 1 - Panthéon-Sorbonne, Paris.

EBERL Markus

2005 Muerte, entierro y ascensión. Ritos funerarios entre los antiguos mayas, Ediciones de la Universidad Autónoma de Yucatán, Mérida.

Fitzsimmons James L.

2006 "Classic Maya Tomb Re-entry", in Pierre Colas, Geneviève Le Fort and Bodil Liljefors Persson (eds.), Jaws of the Underworld. Life, Death and Rebirth among the Ancient Maya [7th European Maya Conference, The British Museum, London, Novelber 2002], Anton Saurwein (Acta Mesoamericana, 16), Markt Schwaben, p. 35-40.

2009 Death and the Classic Maya Kings, University of Texas Press, Austin.

Geller Pamela L.

2014 "Sedimenting social identity", in Gabriel D. Wrobel (ed.), The Bioarchaeology of Space and Place, Springer, New York, p. 15-38.

Goudiaby Hemmamuthé

2017 "Operación II.5bis. En busca de la secuencia funeraria de un conjunto residencial: el Grupo 5N6 'Matapalos"”, in Philippe Nondédéo, Julien Hiquet, Dominique Michelet, and Lilian Garrido (eds.), Proyecto Petén-Norte Naachtun 2015-2018. Informe de le séptima temporada de campo 2016, IDAEH/DEMOPRE, Guatemala, p. 243-282. 
Goudiaby Hemmamuthé

2018 Pratiques funéraires et statut des morts dans les ensembles résidentiels mayas classiques (250-950 apr. J.-C.), Ph.D. dissertation, Archaeology, université Paris 1 - Panthéon Sorbonne, 2 vol.

2019 "Biais archéologique, biais culturel : les anomalies du recrutement funéraire en contexte résidentiel maya", in Elisa Caron-Laviolette, Nanouchka MatomouAdzo, Clara Millot-Richard, and Betty Ramé (eds.), Biais, hiatus et absences en archéologie, Éditions de la Sorbonne (Archéodoct, 12), Paris.

In press "Secondary burials as foundation: a case study from Naacthun (Burial 93, Structure 6N-1)", Mexicon.

Goudiaby Hemmamuthé, Hélène Lacomme, and Walter Omar Schwendener

2016 "Operación II.5bis. En busca de la secuencia funeraria de un conjunto residencial: el Grupo 5N6 'Matapalos'”, in Philippe Nondédéo, Julien Hiquet, Dominique Michelet, Julien Sion, and Lilian Garrido (eds.), Proyecto PeténNorte Naachtun 2015-2018. Informe de la sexta temporada de campo 2015, IDAEH/DEMOPRE, Guatemala, p. 185-248.

HARris Edward C.

1979 Principles of archaeological stratigraphy, Academic Press, London.

Haviland William A.

1963 Excavation of Small Structures in the Northeast Quadrant of Tikal, Guatemala, Ph.D. dissertation, Archaeology, University of Pennsylvania.

1972 "Family size, population estimates, and the ancient Maya", American Antiquity, 37 (1), p. 135-139.

1985 Excavations in Small Residential Groups of Tikal, Groups 4F-1 and 4F-2, University of Pennsylvania Museum of Archaeology and Anthropology (Tikal Reports, 19), Philadelphia.

1988 "Musical Hammocks at Tikal: problems with reconstructing household composition", in Richard R. Wilk, and Wendy Ashmore (eds.), Household and Community in the Mesoamerican Past, University of New Mexico Press, Albuquerque, p. 121-134.

2014a Excavations in Residential Areas of Tikal-Nonelite Groups Without Shrines, University of Pennsylvania Museum of Archaeology and Anthropology (Tikal Reports, 20A), Philadelphia.

2014b Excavations in Residential Areas of Tikal-Nonelite Groups Without Shrines, University of Pennsylvania Museum of Archaeology and Anthropology (Tikal Reports, 20B), Philadelphia.

Haviland William A. and Hattula Moholy-NagY

1992 "Distinguishing the high and mighty from the hoi polloi at Tikal, Guatemala", in Arlen F. Chase, and Diane Z. Chase (eds.), Mesoamerican Elites. An Archaeological Assessment, University of Oklahoma Press, Norman, p. 39-48.

Hertz Robert

1907 “Contribution à une étude sur la représentation collective de la mort”, L'Année sociologique, première série, 10 (1905-1906), p. 48-137. 
The funerary and architectural history of an ancient Maya residential group

HiqueT Julien

2019 Essor monumental et dynamiques des populations: le cas de la cité maya de Naachtun (Guatemala) au Classique ancien (250-600 apr. J.-C.), Ph.D. dissertation, Archaeology, université de Paris 1 - Panthéon-Sorbonne, Paris.

Hiquet Julien, Julien Sion, and Divina Perla-Barrera

In press "Growth, contraction, and mobility in the household at the Classic Maya Center of Naachtun", in Damien B. Marken, and Marie-Charlotte Arnauld (eds.), The Flexible Maya City. Attraction, Contraction, and Planning in Lowland Urban Dynamics, University Press of Colorado, Boulder.

Huchet Jean-Bernard, Grégory Pereira, Yves Gomy, Thomas Keith Philips, Carlos Eduardo Alatorre-Bracamontes, Miguel Vásquez-Bolaños, and Josefina Mansilla

2013 "Archaeoentomological study of a pre-Columbian funerary bundle (mortuary cave of Candelaria, Coahuila, Mexico)", Annales de la Société entomologique de France, 49 (3), p. 277-290.

INOMATA Takeshi

2001 "The power and ideology of artistic creation: elite craft specialists in Classic Maya society", Current Anthropology, 42 (3), p. 321-349.

Lacomme Hélène

2017 “Operación II.5. Variabilidad de los contextos funerarios en Naachtun”, in Philippe Nondédéo, Julien Hiquet, Dominique Michelet, and Lilian Garrido (eds.), Proyecto Petén-Norte Naachtun 2015-2018. Informe de le séptima temporada de campo 2016, IDAEH/DEMOPRE, Guatemala, p. 159-192.

Lamoureux St-Hilaire Maxime

2015 "The last groups standing: living abandonment at the ancient Maya center of Minanha, Belize", Latin American Antiquity, 26 (4), p. 550-569.

LANDA Diego de

1929 [1566] Relation des choses de Yucatan (Relación de las Cosas de Yucatán), Éditions Genet, Paris, 2 vol.

LECLERC Jean

1990 "La notion de sépulture”, Bulletins et mémoires de la Société d'anthropologie de Paris, 2 (3), p. 13-18.

LEDERMANN Sully

1969 Nouvelles tables-type de mortalité, Presses universitaires de France (Travaux et documents de l'INED, 53), Paris.

LEMONNIER Eva and Julio Cotom

2012 "Operación I.1b. Reconocimiento de la zona residencial del sitio: agricultura y subsistencia", in Philippe Nondédéo, Dominique Michelet, Julien Sion, and Carlos Morales-Aguilar (eds.), Proyecto Petén-Norte Naachtun 2010-2014. Informe final de la segunda temporada de campo 2011, IDAEH/DEMOPRE, Guatemala, p. 47-62.

Lemonnier Eva, Julio Cotom, and Julien Hiquet

2014 "La periferia sur de Naachtún: patrón de asentamiento y secuencia de ocupación en una extensa zona residencial", in Bárbara Arroyo, Luis Alberto Méndez Salinas, and Andrea Rojas (eds.), XXVII Simposio de Investigaciones 
Arqueológicas en Guatemala, 2013, Museo Nacional de Arqueología y Etnología/Asociación Tikal, Guatemala, p. 921-934.

LiversRidge Helen M. and Theya I. Molleson

2004 "Variation in crown and root formation and eruption of human deciduous teeth", American Journal of Physical Anthropology, 123, p. 172-180.

LOOPER Matthew George

2009 To be like gods: dance in ancient Maya civilization, University of Texas Press, Austin.

Loten H. Stanley

2007 Additions and Alterations. A Commentary on the Architecture of the North Acropolis, Tikal, Guatemala, University of Pennsylvania Museum of Archaeology and Anthropology (Tikal Reports, 34A), Philadelphia.

LuCERo Lisa $\mathrm{J}$.

2003 "The politics of ritual: the emergence of Classic Maya rulers", Current Anthropology, 44 (4), p. 523-558.

Mansilla Lory Josefina and Carmen PiJoAn Aguadé

2000 "Evidencia de treponematosis en la cueva de la Candelaria, Coahuila, con énfasis en un bulto mortuorio infantil", Chungara. Revista de Antropología Chilena, 32 (2), p. 207-210.

MARRADES Maxime

2013 Attitudes thérapeutiques face à la fusion/gémination dentaire, Ph.D. dissertation, Medicine, université de Nantes.

MAYer Karl Herbert

2010 "Cover: three Maya unprovenanced "Tikal dancer" plates", Mexicon, 32 (5), p. 97-102.

McAnany Patricia A.

1998 "Ancestors and the Classic Maya built environment", in Stephen D. Houston (ed.), Function and Meaning in Classic Maya Architecture. A Symposium at Dumbarton Oaks, 7th and 8th October 1994, Dumbarton Oaks Research Library and Collection, Washington (DC), p. 271-298.

2004 K'axob. Ritual, Work and Family in an Ancient Maya Village, Cotsen Institute of Archaeology (Monumenta Archaeologica, 22), University of California, Los Angeles.

2013 [1995] Living with the Ancestors. Kinship and Kingship in Ancient Maya Society, revised édition, Cambridge University Press, Cambridge.

Mickleburgh Hayley L., and Daniel J. Wescott

2018 "Controlled experimental observations on joint disarticulation and bone displacement of a human body in an open pit: implications for funerary archaeology", Journal of Archaeological Science. Reports, 20, p. 158-167.

Micozzi Marc S.

1991 Postmortem Change in Human and Animal Remains. A Systematic Approach, Charles C. Thomas, Springfield.

Moorrees Coenraad F. A., Elizabeth A. FAnNing, and Edward E. Hunt JR.

1963 "Age variation of formation stages for ten permanent teeth", Dental Research, 42 (6), p. 1490-1502. 
The funerary and architectural history of an ancient Maya residential group

Morton Shawn G.

2005 "Mapeo y reconocimiento arqueológico en Naachtun", in Martin Rangel, and Kathryn Reese-Taylor (eds.), Proyecto arqueológico Naachtun, Informe No. 1. Primera temporada de campo, IDAEH, Guatemala, p. 100-103.

Murail Pascal, Jaroslav Bruzek, Francis HouËT, and Eugenia CunHA

2005 "DSP: a tool for probabilistic sex diagnosis using worldwide variability in hip-bone measurements", Bulletins et mémoires de la Société d'anthropologie de Paris, 17 (3-4), p. 167-176.

Nalda Enrique, Adriana Velazquez, Sandra Balanzario, and Alan Maciel

1997 Proyecto Arqueologico Sur de Quintana Roo. Kohunlich 1993-1994, Archivo técnico del Consejo de arqueología, INAH, México, 6 vol.

Newman Sarah E.

2019 "Rubbish, reuse and ritual at the ancient maya site of El Zotz, Guatemala", in Journal of Archaeological Method and Theory, 26 (2), p. 806-843.

NondÉDÉo Philippe

2017 "Naachtun: organisation, essor et histoire d'une capitale régionale maya", Compte rendus de l'Académie des Inscriptions et Belles-Lettres 2016, juilletoctobre (fascicule 3), p. 1211-1228.

NondéDÉo Philippe, Alfonso LaCAdena, and Ignacio CASES

2019 “Teotihuacanos y Mayas en la 'Entrada' de 11 EB' (378 d.C.): nuevos datos de Naachtun, Peten, Guatemala", Revista Española de Antropología American, 49 (especial), p. 53-75.

Nondédéo Philippe, Carlos Morales-Aguilar, Alejandro Patiño-Contreras, Mélanie Forné, Chloé Andrieu, Julien Sion, Dominique Michelet, Marie-Charlotte Arnauld, Céline Gillot, Monica De Léon, Julio Cotom, Eva Lemonnier, Grégory Pereira, and Isaac BArrientos JuÁrez

2012 "Prosperidad económica en Naachtún: resultados de las dos primeras temporadas de investigación", in Bárbara Arroyo, Lorena Paiz Aragón, and Héctor Mejía (eds.), XXV Simposio de Investigaciones Arqueológicas en Guatemala, 2011, Museo Nacional de Arqueología y Etnología/Ministerio de Cultura y Deportes/Instituto de Antropología e Historia/Asociación Tikal, Guatemala, p. 227-235.

NondédÉo Philippe, Alejandro Patiño, Julien Sion, Dominique Michelet, and Carlos Morales-Aguilar

2013 "Crisis múltiples en Naachtún: aprovechadas, superadas e irreversibles", in Marie-Charlotte Arnauld, and Alain Breton (eds.), Millenary Maya Societies. Past Crises and Resilience. Sociedades mayas milenarias: crisis del pasado y resiliencia [on line], Mesoweb, p. 122-147, http://www.mesoweb.com/ publications/MMS/, consulted 26/05/2020.

NondédÉo Philippe, Julien Sion, Alfonso Lacadena, Ignacio Cases, and Julien Hiquet

In press "From kings to nobles: the political-historical context of Naachtun at the end of the Classic Period", in Tsubasa Okoshi, Arlen Chase, Philippe Nondédéo, and Marie-Charlotte Arnauld (eds.), Maya Kingship: Rupture and Transformation from Classic to Postclassic Times, University Press of Florida, Gainesville.

Novotny Anna

2015 Creating Community. Ancient Maya Mortuary Practice at Mid-Level Sites in the Belize River Valley, Belize, Arizona State University, Tempe. 
OBLADO Micaela Nerio

2011 Preclassic Maya Funerary Patterns in Northern Belize. An Analysis of Internment Attributes from Colha, Cuello and K'axob, Ph.D. dissertation, Archaeology, University of Texas.

Patiño-Contreras Alejandro

2016 "Explaining Tzakol: social interaction during the Early Classic. A view from Naachtún, Petén, Guatemala”, Estudios de Cultura Maya, 48, p. 39-70.

PAtrois Julie and Philippe NondÉDÉo

In press "Las figurillas de Naachtun: ofrendas dedicatorias y funerarias", in Miriam Judith Gallegos, and Patricia Horcajada (eds.), Figurillas mesoamericanas del Clásico. Una mirada caleidoscópica a sus contextos, representaciones y usos, INAH, México, p. 230-282.

Peressinotto David

2007 Chronologie de la dislocation articulaire du squelette axial et des ceintures au cours de la décomposition du cadavre. Apports à l'analyse des sépultures, Ph.D. dissertation, Physical anthropology, Université de Bordeaux, Bordeaux.

PEREIRA Grégory

2013 "Ash, dirt and rock: burial practices at Rio Bec", Ancient Mesoamerica, 24 (2), p. 449-468.

Pereira Grégory and Dominique Michelet

2004 "Gobernantes mayas en lechos de muerte : el caso de Balamku, un patrón funerario del Clásico temprano", in Rafael Cobos (ed.), Culto funerario en la sociedad maya. Memoria de la cuarta mesa redonda de Palenque, Conaculta/ INAH, México, p. 333-368.

PuRdue Louise

2018 “Operación IV.7. Agricultura y subsistencia”, in Philippe Nondédéo, Dominique Michelet, Johann Begel, and Lilian Garrido (eds.), Proyecto PeténNorte Naachtun 2015-2018. Informe de la octava temporada de campo 2016, IDAEH/DEMOPRE, Guatemala, p. 345-356.

Purdue Louise and Hemmamuthé Goudiaby

2017 “Operación IV.7. Agricultura y subsistencia”, in Philippe Nondédéo, Dominique Michelet, Julien Hiquet, and Lilian Garrido (eds.), Proyecto Petén-Norte Naachtun 2015-2018. Informe de la séptima temporada de campo 2016, IDAEH/DEMOPRE, Guatemala, p. 411-418.

Purdue Louise, Cyril Castanet, Lydie Dussol, Eva Lemonnier and Aline Garnier

2016 "Where and how did the Maya practice agriculture in the Classic Period city of Naachtun, Guatemala?", Paper presented at the 81st SAA Annual Meeting, Orlando, 5-10 April.

Rangel Martin and Kathryn ReESE-TAYlor

2005 Proyecto arqueológico Naachtun. Informe de la primera temporada de campo, IDAEH, Guatemala.

RUPPERT Karl and John H. Denison JR.

1943 Archaeological reconnaissance in Campeche, Quintana Roo and Petén, Carnegie Institution of Washington (Publications, 543), Washington (DC). 
The funerary and architectural history of an ancient Maya residential group

Scherer Andrew K.

2015 Mortuary Landscapes of the Classic Maya. Rituals of Body and Soul, University of Texas Press, Austin.

Scheuer J. Louise, Jonathan H. Musgrave, and Suzanne P. Evans

1980 "The estimation of late fetal and perinatal age from limb bone length by linear and logarithmic regression", Annals of Human Biology, 7 (3), p. 257-265.

Sion Julien

2014 “Operación II.3b. Excavaciones selectivas en el Complejo B-Sur: los Patios 31, 34 y 35", in Philippe Nondédéo, Dominique Michelet, Julien Sion, and Carlos Morales-Aguilar (eds.), Proyecto Petén-Norte Naachtun 2010-2014. Informe de la cuarta temporada de campo 2013, IDAEH/DEMOPRE, Guatemala, p. 161-258.

2016 La caractérisation socio-économique des élites mayas au Classique terminal (800-959/1000 apr. J.-C.) : le Groupe B-sud de Naachtun, Ph.D. dissertation, Archaeology, université Paris 1 - Panthéon-Sorbonne.

Sion Julien, Marie-Charlotte Arnauld, and Monica Antillon

2012 “Operación II.3a. Excavaciones selectivas en el patio 28: los edificios 6O7, 608 y 609", in Philippe Nondédéo, Dominique Michelet, Julien Sion, and Carlos Morales-Aguilar (eds.), Proyecto Petén-Norte Naachtun 2010-2014. Informe final de la segunda temporada de campo 2011, IDAEH/DEMOPRE, Guatemala, p. 80-135.

Sмiтн Augustus Ledyard

1950 Uaxactun, Guatemala. Excavations of 1931-1937, Carnegie Institution of Washington, Washington (DC).

Stuart David

1998 “"The fire enters his house': architecture and ritual in Classic Maya texts", in Stephen D. Houston (ed.), Function and Meaning in Classic Maya Architecture. A Symposium at Dumbarton Oaks, 7th and 8th October 1994, Dumbarton Oaks Research Library and Collection, Washington (DC), p. 373-425.

TIESLER Vera

1999 Razgos bioculturales entre los antiguos mayas. Aspectos arqueológicos y sociales, Ph.D. dissertation, Physical anthropology, Facultad de Filosofía y Letras, Universidad Nacional Autónoma de México.

2018 "The fiery dead: igniting human bodies in the Maya northern lowlands", in Andrew K. Scherer, and Vera Tiesler (eds.), Smoke, Flames, and the Human Body in Mesoamerican Ritual Practice, Dumbarton Oaks Research Library and Collection, Washington (DC), p. 205-250.

Tiesler Vera and Luz Evelia CAmpaña ValenZuela

2004 "Sacrificio y tratamiento ritual del cuerpo humano en la antigua sociedad maya: el caso del Depósito E-1003 de Becán, Campeche", Arqueología, 33 (segunda época), p. 32-46.

Tiesler Vera, Andrea Cucina, T. Kam Manahan, Douglas T. Price, Traci Ardren, and James H. BurToN

2010 "A taphonomic approach to late Classic Maya mortuary practices at Xuenkal, Yucatan, Mexico", Journal of Field Archaeology, 35 (4), p. 365-379. 


\section{WeISS-KREJCI Estella}

2003 "The Maya corpse: body processing from Preclassic to Postclassic times in the Maya highlands and lowlands", in Pierre Robert Colas, Geneviève Le Fort, and Bodil Liljefors Persson, Jaws of the Underworld. Life, Death and Rebirth Among the Ancient Maya, Anton Saurwein (Acta Mesoamericana, 16), Markt Schwaben, p. 71-114.

WeLsh William Bruce Maxwell

1988 An Analysis of Classic Lowland Maya Burials, Archaeopress (BAR International Series, 409), Oxford.

Wrobel Gabriel D., Marie E. Danforth, and Carl Armstrong

2002 "Estimating sex of Maya skeletons by discriminant function analysis of long-bone measurements from the protohistoric Maya site of Tipu, Belize", Ancient Mesoamerica, 13 (2), p. 255-263.

ZeHRT Claudia

2012 "Fate and fortune: the life history of a Maya commoner residential Courtyard at Minanha, Belize", in Philippe Nondédéo, and Alain Breton (eds.), Maya Daily Lives. Proceedings of the 13th European Maya Conference, Paris, December 5-6, 2008, Markt Schwaben (Acta Mesoamericana, 28), Anton Saurwein, p. 65-75. 